\title{
Salinity and food security in southwest coastal Bangladesh: impacts on household food production and strategies for adaptation
}

\author{
Yukyan Lam ${ }^{1}$ (D) - Peter J. Winch ${ }^{1} \cdot$ Fosiul Alam Nizame ${ }^{2}$ Elena T. Broaddus-Shea ${ }^{3} \cdot$ Md. Golam Dostogir Harun $^{2}$. \\ Pamela J. Surkan ${ }^{1}$
}

Received: 3 January 2021 / Accepted: 23 May 2021 / Published online: 29 July 2021

(C) The Author(s) 2021

\begin{abstract}
The rising salinity of land and water is an important, but understudied, climate change-sensitive trend that can exert devastating impacts on food security. This mixed methods investigation combines salinity testing with qualitative research methods to explore these impacts in one of the most salinity-affected regions in the world - the Ganges River Delta. Data collection in 2015 and 2016 undertaken in Bangladesh's southwest coastal region and Dhaka consisted of 83 in-depth household and stakeholder interviews, six community focus groups, and salinity testing of 27 soil and 45 surface and groundwater samples. Results show that household food production is a multifaceted cornerstone of rural livelihood in the southwest coastal region, and virtually every component of it - from rice plantation and homestead gardening to livestock cultivation and aquaculture-is being negatively affected by salinity. Although households have attempted multiple strategies for adapting food production, effective adaptation remains elusive. At the community level, improved irrigation and floodplain management, as well as restrictions on saltwater aquaculture to abate salinity, are viewed as promising interventions. However, the potential of such measures remains unrealized on a broad scale, as they require a level of external resources and regulation not yet provided by the NGO and government sectors. This study elucidates issues of accessibility, equity, and governance surrounding agricultural interventions for climate change-related salinity adaptation, and its findings can help inform the community of organizations that will increasingly need to grapple with salinity in order to guarantee food security in the context of environmental change.
\end{abstract}

Keywords Salinity $\cdot$ Saltwater intrusion $\cdot$ Food security $\cdot$ Climate change $\cdot$ Climate change adaptation $\cdot$ Bangladesh

Yukyan Lam

ylam.pub@gmail.com

Peter J. Winch

pwinch@jhu.edu

Fosiul Alam Nizame

fosiul@icddrb.org

Elena T. Broaddus-Shea

ELENA.BROADDUS@cuanschutz.edu

Md. Golam Dostogir Harun

dostogirharun@icddrb.org

Pamela J. Surkan

psurkan@jhu.edu

1 Department of International Health, Johns Hopkins Bloomberg School of Public Health, Baltimore, MD, USA

2 International Centre for Diarrhoeal Disease Research, Dhaka, Bangladesh

3 Department of Family Medicine, University of Colorado Anschutz Medical Campus, Aurora, CO, USA

\section{Introduction}

Global environmental change poses complex threats to health and livelihoods, and food security is one of the major impact pathways. The literature on climate change vulnerability links warming temperatures, precipitation variability, ocean acidification, drought, and flooding to food insecurity and the breakdown of food systems (Field et al., 2014; Myers et al., 2017). However, less attention has been paid to another environmental change that can exert silent, but devastating, impacts on food production - the rising salinity of land and water. Although other human drivers also influence salinity, the Intergovernmental Panel on Climate Change (IPCC) reports with high confidence that the landward intrusion of saltwater is increasing and constitutes a climate change-sensitive trend that will lead to the salinization of groundwater, surface water, and soil resources, particularly in low-lying coastal areas, river deltas, and estuaries (Oppenheimer et al., 2019; Wong et al., 2014). This occurs gradually via sea level rise, land 
subsidence, and temperature and precipitation changes that affect aquifer recharge, and acutely from storm surge and wave overwash in the aftermath of extreme weather (Cisneros et al., 2014; Cramer et al., 2014; Oppenheimer et al., 2019; Werner et al., 2013; Wong et al., 2014). Particularly at low elevations, saltwater intrusion can lead to soil salinization, a major cause of soil degradation affecting plant germination, biomass production, and yield (Oppenheimer et al., 2019).

The world's mega-deltas, which support the livelihoods of hundreds of millions of people, are hot spots for this type of change. Chief among the mega-deltas is the Ganges River Delta, the most populous river basin in the world, home to over 100 million inhabitants at a density of nearly 1300 people per square kilometer (Ericson et al., 2006; Szabo et al., 2016a). Worldwide, the Ganges River Delta is among the most environmentally sensitive to the effects of climate change, sea level rise, and saltwater intrusion, in conjunction with human activity and land use (Cruz et al., 2007; M. A. Islam et al., 2019; Oppenheimer et al., 2019; Szabo et al., 2016a). As sea levels rise and groundwater extraction lowers the water table, saltwater from the Bay of Bengal can increasingly intrude laterally into the coastal aquifers of the Bengal Basin, leading to their salinization over the long-term (see Fig. 1) (M. M. Rahman \& Bhattacharya, 2014; Salehin et al., 2018). Significant seasonal patterns in surface water salinity have already been observed, with saltwater pushing inland into rivers and canals when droughts, dry season, and upstream dams reduce the volume of downstream flow of the Ganges and its distributaries (Salehin et al., 2018). The surface or shallow saltwater that has intruded inland can filter down vertically to salinize groundwater resources, or seep into the surrounding land to salinize the soil (Salehin et al., 2018). Acute increases in salinity have also been documented in the delta, as a result of flooding and storm surges from severe tropical cyclones in the North Indian Ocean, such as Cyclone Sidr in 2007 and Cyclone Aila in 2009 (Kabir et al., 2016; Salehin et al., 2018). Such increases can take years, i.e., several rainy seasons, to be flushed out (Rabbani et al., 2013).

Situated in the heart of the Ganges River Delta, Bangladesh's southwest coastal region faces profound impacts on food production from salinity. For the region's largely rural communities, food security and overall welfare depend on the ability to use land productively. Bangladesh's coastal population engages in commercial agricultural livelihoods - including crops, horticulture, and fisherieswhile also relying on subsistence homestead food production activities. During the driest months of the year (roughly January through May), much of the region's arable land becomes too saline for crops to grow (M. M. Rahman \& Bhattacharya, 2014). At the same time, there is a lack of quality irrigation water. The surface waters found in canals and rivers become too saline for irrigation use and contribute to soil salinity as they seep into surrounding land, while aquifer water quality also becomes compromised from the exchange of shallow groundwater and saline surface water, groundwater pumping and lateral saltwater intrusion, and a lack of precipitation that would recharge the aquifer with fresh rainwater (Salehin et al., 2018). The resulting impacts to food production threaten to undo the country's recent progress in child and maternal nutrition, and to exacerbate a malnutrition burden that remains much higher than that of other low- and middle-income countries (LMICs) (Das et al., 2019; Global Nutrition Report, 2020).
Fig. 1 Saltwater intrusion into groundwater (US Environmental Protection Agency, 2016)

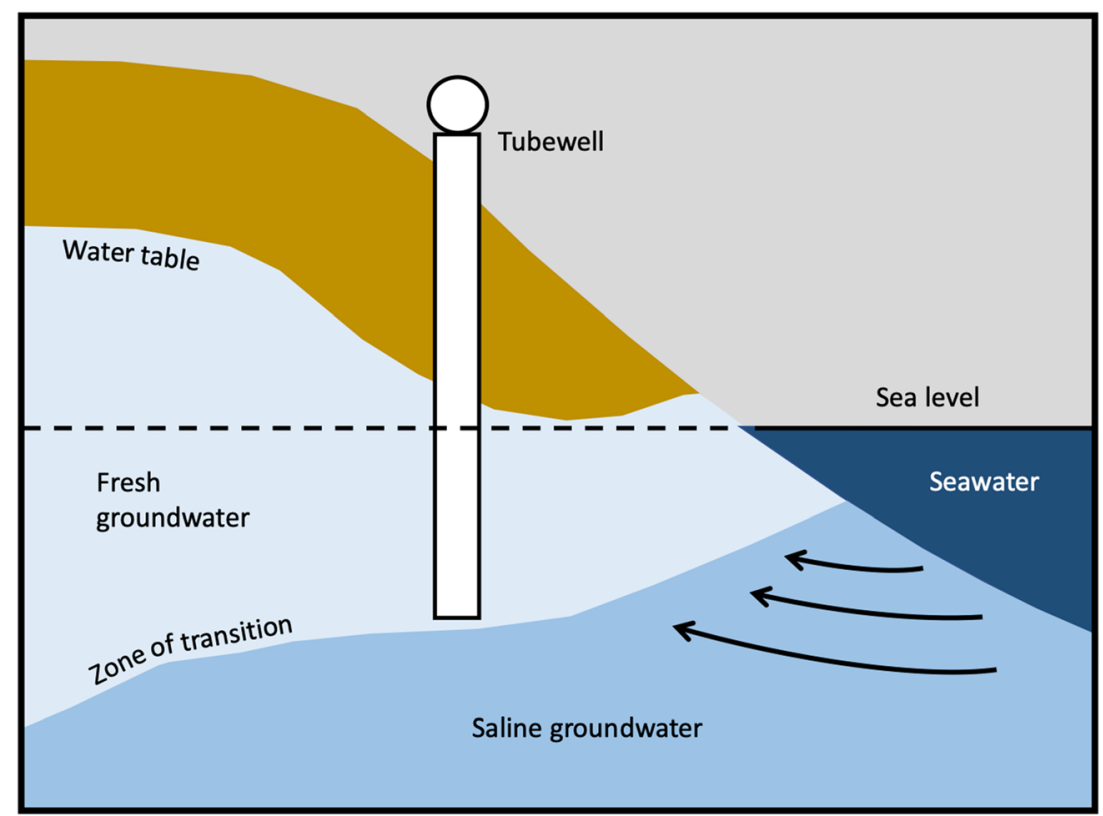


Both climate change and human activity are expected to intensify salinity in the region, with increasingly serious consequences for agricultural productivity and food security (Salehin et al., 2018). Over recent decades, saltwater shrimp aquaculture has rapidly proliferated in the region due to its apparent profitability and suitability for salinity-affected areas. Yet this type of aquaculture entails the deliberate retention of saltwater through a system of sluice gates and embankments and itself drives further salinization of land and water resources, highlighting the complexity of adapting agriculture to rising salinity (R. Rahman et al., 2014; Salehin et al., 2018). Interventions to help residents cope with salinity in soil and water-including projects related to freshwater infrastructure and modified agricultural practices and inputs - are being tried by government and non-governmental organizations, but the magnitude of the problem remains significant. The Bangladesh government estimates that between 2015 and 2030, $\$ 3$ billion USD and $\$ 8$ billion USD will be needed for adaptation measures specifically targeting "salinity intrusion and coastal protection" and "food security and livelihood and health protection (including water security)," respectively (Bangladesh Ministry of Environment and Forests, 2015).

With human and environmental factors projected to drive salinity upward, a better understanding of how to safeguard the food security of communities living in this climatesensitive region is urgently needed. Rather than focusing on a single sector or type of industry, what is required is more nuanced knowledge of community-level experiences with salinity, its impacts on household food security, and communities' own assessment of adaptation strategies. To fill this gap, we conducted a mixed methods investigation in Bangladesh's southwest coastal region, drawing on the input of community members, civil society, and government officials, as well as salinity data from soil samples. A unique combination of salinity testing and qualitative research allowed us firstly to understand the magnitude of the problem, and secondly to probe the extent to which adaptation options meet or fail to meet the challenge. Our study critically examines adaptation responses in context, responding to recent calls for implementation research to understand why interventions on household agricultural production do or do not work (Fiorella et al., 2016).

\section{Materials and methods}

\subsection{Study setting}

Bangladesh is a low-lying country with 440 miles of coastline. Its coastal zone, $62 \%$ of which sits less than three meters above sea level, is divided into three regions: southwest, south-central, and southeast (Nishat \& Mukherjee, 2013). Bordering India to the west and the Bay of Bengal to the south, the southwest coastal region comprises the districts of Satkhira, Khulna, and Bagerhat. Each district is divided into sub-districts and each sub-district into unions, the smallest rural administrative unit.

Soil salinity in Bangladesh's southwest coastal region varies depending on the time of year, the year itself, and the location (Sarwar \& Islam, 2013). Saltwater currently intrudes as far as 110 miles inland, seeping in by way of rivers and channels, especially from January through June, when there is less rainfall and insufficient downstream flow of freshwater from the Ganges and its distributaries (Food and Agriculture Organization of the United Nations, 2009; Haque, 2006; M. H. Rahman et al., 2011a). Soil salinity is strongly associated with river water salinity in the southwest coastal region (Salehin et al., 2018). The association is weaker moving farther inland, where other factors (such as depth to the groundwater table and rainfall) also play a role, and soil salinity can remain high even when river salinity is lower (Salehin et al., 2018).

Generally, areas closer to the shoreline are more salineprone (Sarwar \& Islam, 2013). However, salinity levels are also greatly influenced by land management, particularly by how sluice gates (Fig. 2(a)) are used to retain and direct water in and around polders, large tracts of floodplain enclosed by mud embankments (Fig. 2(b)) (Ali, 2006; M. A. Islam et al., 2019). Originally constructed in the 1960s and 1970s, polders were intended to protect the coastal zone from saltwater intrusion and tidal flooding and allow for more intensive farming by regulating water flow - draining excess water out from the enclosed areas into rivers and canals funneled between the artificial embankments. Their management has been complicated by competing interests, maintenance challenges, and the physical environment (Dewan et al., 2015; Pukinskis, 2015).

Between 1973 and 2009, Bangladesh's Soil Resource Development Institute (SRDI) observed increases in soil salinity across the southwest coastal region, registering not only more area affected by salinity overall, but a significant increase in the amount of land experiencing high-range salinity levels (Arbol et al., 1988; Soil Resources Development Institute, 2010). Over that period, there was an estimated $225 \%$ increase in the amount of land with salinity values considered 'saline' ( 8000 to $16,000 \mu \mathrm{S} / \mathrm{cm}$ ) or 'highly saline' (greater than $16,000 \mu \mathrm{S} / \mathrm{cm}$ ) - i.e., land that would be unsuitable for all but a few extremely saline-tolerant crops. (See Tables 1 and 2.)

Moreover, studies sampling surface water and groundwater sources throughout the southwest coastal region have found salinity levels that routinely exceed thresholds for water that is suitable for irrigation (Food and Agriculture Organization of the United Nations, 2009; M. H. Rahman et al., 2011a; Shammi et al., 2016). For purposes of irrigation, key thresholds for water are around $700 \mu \mathrm{S} / \mathrm{cm}$ (measured as electroconductivity) or $450 \mathrm{mg} / \mathrm{L}$ (measured as total dissolved 


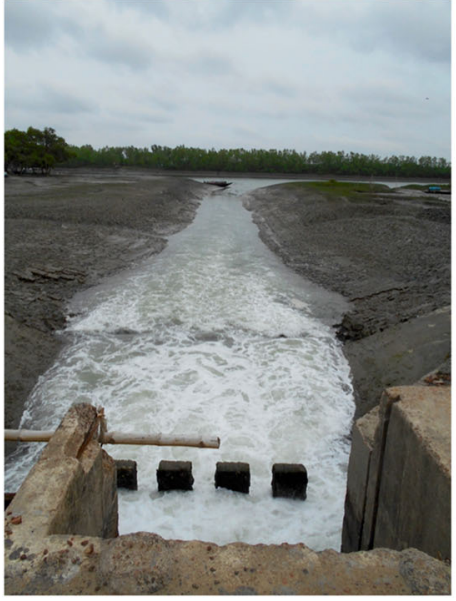

(a)

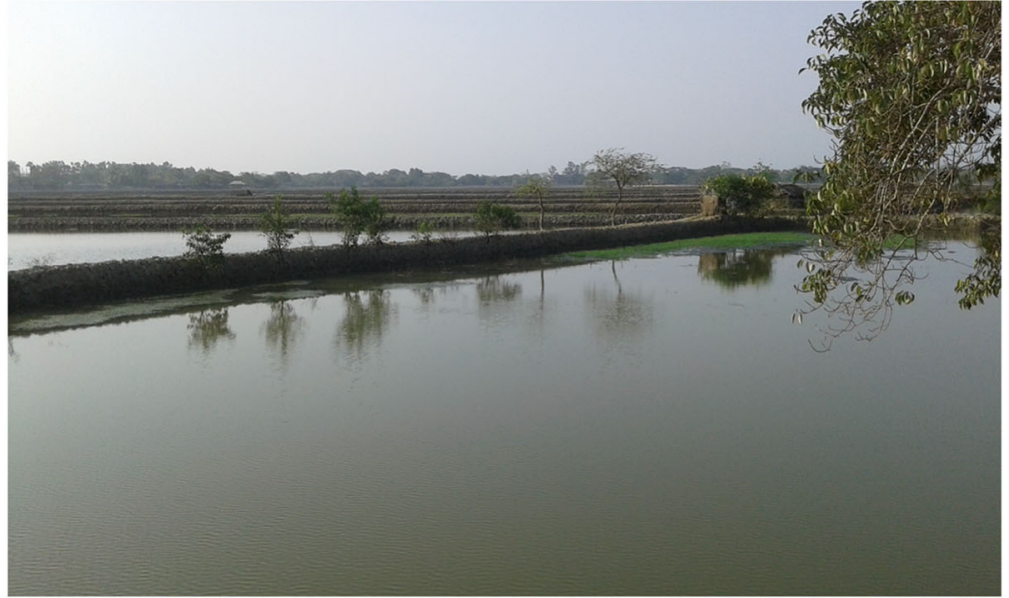

(b)

Fig. 2 Sluice gate (a) and polder (b)

solids), when there will be some restrictions to use, and around 2500 or $3000 \mu \mathrm{S} / \mathrm{cm}$ or $2000 \mathrm{mg} / \mathrm{L}$, when water is so saline that its use for irrigating typical crops is extremely limited. (See Table 3.) Studies of deep groundwater sources in Satkhira (M. A. T. M. Rahman et al., 2012) and Khulna (Food and Agriculture Organization of the United Nations, 2009) have revealed highly saline water, requiring moderate to severe restrictions on use for irrigation, while studies of surface water from the region's rivers, canals, and ponds have revealed the potential for even higher salinity levels, especially in the months leading up to the start of the monsoons in June (Food and Agriculture Organization of the United Nations, 2009; Lam et al., 2018). Although few long-term salinity records are available, as with soil there appears to be an overall upward trend in water salinity. A few studies have noted increases in average yearly salinity in specific water sources, such as the Kazibacha River in Khulna, the Rampal River in Bagerhat, and the Kakshiali River in Satkhira (M. H. Rahman et al., 2011a), as well as increases in the highest recorded salinity levels in Kaliganj sub-district in Satkhira (M. H. Rahman et al., 2011a) and the Rupsa River in Khulna (Food and Agriculture Organization of the United Nations, 2009; M. M. Rahman et al., 2000).
At the same time, Bangladesh's coastal zone is characterized by a growing population and livelihoods that are deeply dependent on the land. Approximately 40 million people reside in an area of about $47,000 \mathrm{~km}^{2}$, with a projected growth to 60 million by 2050 (The World Bank and US Geological Survey, 2010). According to a recent synthesis of data from the Bangladesh 2012 Yearbook of Agricultural Statistics, the southwest coastal region within the coastal zone is home to 14 million people at a density of 750 people per $\mathrm{km}^{2}$, and $56 \%$ of households are effectively landless (owning less than half an acre of land) (Lázár et al., 2020). The Bangladesh Agriculture Census, from its 1996 to 2008 to preliminary 2019 results, has shown slight fluctuations in the percentage of completely landless households, from $10 \%$ to $13 \%$ to $8 \%$ nationally and from $8 \%$ to $10 \%$ to $7 \%$ for Khulna division, which includes the three southwest coastal districts (Bangladesh Bureau of Statistics, 2019).

Persisting nutrition and food security challenges are reflected in Bangladesh's 2017-2018 Demographic and Health Survey (DHS) (National Institute of Population Research and Training (NIPORT) and ICF International, 2020). In rural Bangladesh, 33\%, $8 \%$, and $23 \%$ of children under five were considered stunted (short for their age),

Table 1 Soil salinity (electroconductivity, $\mathrm{EC}_{\mathrm{e}}$, in microSiemens per $\mathrm{cm}$ ) in Khulna, Bagerhat, and Satkhira Districts: 1973, 2000,2009 (Soil Resources Development Institute, 2010)

\begin{tabular}{|c|c|c|c|c|c|c|c|c|c|c|c|c|c|c|c|c|}
\hline \multirow[t]{2}{*}{ District } & \multicolumn{3}{|c|}{$\begin{array}{l}\text { Salt affected area (in } \\
1000 \text { ha) }\end{array}$} & \multicolumn{3}{|c|}{$\begin{array}{l}\text { Slightly saline } 2000- \\
4000 \mu \mathrm{S} / \mathrm{cm}\end{array}$} & \multicolumn{3}{|c|}{$\begin{array}{l}\text { Moderately saline } \\
4100-8000 \mu \mathrm{S} / \mathrm{cm}\end{array}$} & \multicolumn{3}{|c|}{$\begin{array}{l}\text { Saline } 8000- \\
16,000 \mu \mathrm{S} / \mathrm{cm}\end{array}$} & \multicolumn{3}{|c|}{$\begin{array}{l}\text { Highly saline } \\
>16,100 \mu \mathrm{S} / \mathrm{cm}\end{array}$} & \multirow[t]{2}{*}{$\begin{array}{l}\text { Four-decade increase } \\
\text { in total affected area }\end{array}$} \\
\hline & '73 & $' 00$ & '09 & $\cdot 73$ & '00 & '09 & $\cdot 73$ & '00 & '09 & '73 & $' 00$ & '09 & '73 & '00 & '09 & \\
\hline Khulna & 120 & 145 & 148 & 14 & 29 & 24 & 93 & 38 & 27 & 14 & 60 & 48 & 9.8 & 20 & 31 & $23.3 \%$ \\
\hline Bagerhat & 108 & 125 & 131 & 8.3 & 36 & 32 & 77 & 43 & 43 & 3.6 & 41 & 53 & 0 & 6.7 & 9.2 & $21.4 \%$ \\
\hline Satkhira & 146 & 147 & 153 & 27 & 29 & 31 & 86 & 39 & 33 & 35 & 61 & 70 & 11 & 22 & 29 & $4.62 \%$ \\
\hline TOTAL & 374 & 417 & 432 & 49 & 94 & 88 & 255 & 120 & 102 & 52 & 161 & 169 & 21 & 48 & 68 & $15.4 \%$ \\
\hline
\end{tabular}


Table 2 Soil salinity classes and crop growth (Arbol et al., 1988)

\begin{tabular}{lll}
\hline Soil salinity class & $\mathrm{EC}_{\mathrm{e}}(\mu \mathrm{S} / \mathrm{cm})$ & Effect on crops \\
\hline Non-saline & $0-2000$ & Salinity effects negligible \\
Slightly saline & $2000-4000$ & Yields of sensitive crops may be restricted \\
Moderately saline & $4000-8000$ & Yields of many crops are restricted \\
Strongly saline & $8000-16,000$ & Only tolerant crops yield satisfactorily \\
Very strongly saline & $>16,000$ & Only a few very tolerant crops yield satisfactorily \\
\hline
\end{tabular}

wasted (thin for their height), and underweight, respectively. Khulna division had prevalence rates of $26 \%, 8 \%$, and $19 \%$ for stunting, wasting, and underweight, respectively. Despite governmental and NGO initiatives on nutrition and food security (Ishrat, 2013) and some advances in health indicators over the past decade (Global Nutrition Report, 2020), nutritional status continues to be one of the country's most pressing challenges.

Study sites within Bangladesh's southwest coastal region were purposively chosen with a focus on areas where salinity was a moderate to significant problem, and where some level of adaptation in methods for cultivation and managing household water had been observed. Site selection, conducted in February 2015, was based on SRDI salinity data, consultations with local officials and NGOs, and in-person visits to candidate sites. SRDI salinity data were not specific enough to narrow down to a community-level scale; thus we also had to rely on consultations with stakeholders, as well as visits where we could sample soil and water, speak with households, and observe local conditions at the candidate sites. The final selected sites were Moshamari village (Tildanga Union) in the Dacope sub-district of Khulna; Dokin Chandpai village (Chandpai Union) in the Mongla sub-district of Bagerhat, and Khagraghat village (Munshiganj Union) in the Shyamnagar sub-district of Satkhira. (See Fig. 3.)

\subsection{Study design}

This was a mixed methods investigation, using a combination of qualitative research methods (in-depth interviews and focus groups discussions), participatory systematic data collection, field observations, and salinity testing. In-depth interviews (IDIs) and focus group discussions (FGDs) were semi-structured, with guides developed in English and translated into Bangla. Systematic data collection consisted of participant rating and ranking exercises. Field observations were guided by a household inventory/questionnaire. All instruments are available upon request.

\subsection{Data collection}

There were three components of data collection: community-level data collection in the southwest coastal region, salinity testing which accompanied communitylevel data collection, and stakeholder-level data collection with government officials and NGOs in the region and Dhaka. The data collection team consisted of three public health researchers, two female and one male. Two were Bangladeshi and the third was a female $\mathrm{PhD}$ student from the United States. All members had graduate-level training and experience in qualitative research methods. During data collection, the team met nightly to debrief, share observations, and supplement notes that were taken during each data collection activity.

Written consent was obtained from all participants. The study was approved by the Institutional Review Board of Johns Hopkins Bloomberg School of Public Health, and the Research and Ethics Review Committees of the International Centre for Diarrhoeal Disease Research, Bangladesh (icddr,b).

Table 3 Irrigation water salinity classification systems applied in Bangladesh

\begin{tabular}{|c|c|c|c|c|}
\hline Source & Level of restriction on use / level of salinity & & & Study applied in \\
\hline $\begin{array}{l}\text { FAO (TDS) } \\
\text { (Ayers \& Wescot, } \\
\quad 1985)\end{array}$ & $\begin{array}{c}\text { No restrictions on } \\
\text { use }<450 \mathrm{mg} / \mathrm{L}\end{array}$ & $\begin{array}{l}\text { Slight to moderate use } \\
\text { restrictions } \\
450-2000 \mathrm{mg} / \mathrm{L}\end{array}$ & $\begin{array}{l}\text { Severe use restrictions } \\
>2000 \mathrm{mg} / \mathrm{L}\end{array}$ & $\begin{array}{l}\text { Shahid (Shahid et al., } \\
\text { 2006) }\end{array}$ \\
\hline $\begin{array}{l}\text { FAO (EC) } \\
\text { (Ayers \& Wescot, } \\
\text { 1985) }\end{array}$ & $\begin{array}{l}\text { No restrictions on } \\
\text { use }<700 \mu \mathrm{S} / \mathrm{cm}\end{array}$ & $\begin{array}{l}\text { Slight to moderate use } \\
\text { restrictions } \\
700-3000 \mu \mathrm{S} / \mathrm{cm}\end{array}$ & $\begin{array}{l}\text { Severe use restrictions } \\
>3000 \mu \mathrm{S} / \mathrm{cm}\end{array}$ & $\begin{array}{l}\text { Rahman (M. A. T. M. } \\
\quad \text { Rahman et al., 2012) }\end{array}$ \\
\hline $\begin{array}{l}\text { Rao (EC) (Rao, } \\
2006)\end{array}$ & Low $<250 \mu \mathrm{S} / \mathrm{cm}$ Medium 250-750 $\mu \mathrm{S} / \mathrm{cm}$ & High $750-2250 \mu \mathrm{S} / \mathrm{cm}$ & $\begin{array}{l}\text { Very high } \\
>2250 \mu \mathrm{S} / \mathrm{cm}\end{array}$ & $\begin{array}{l}\text { Rahman (M. A. T. M. } \\
\text { Rahman et al., 2012) }\end{array}$ \\
\hline
\end{tabular}




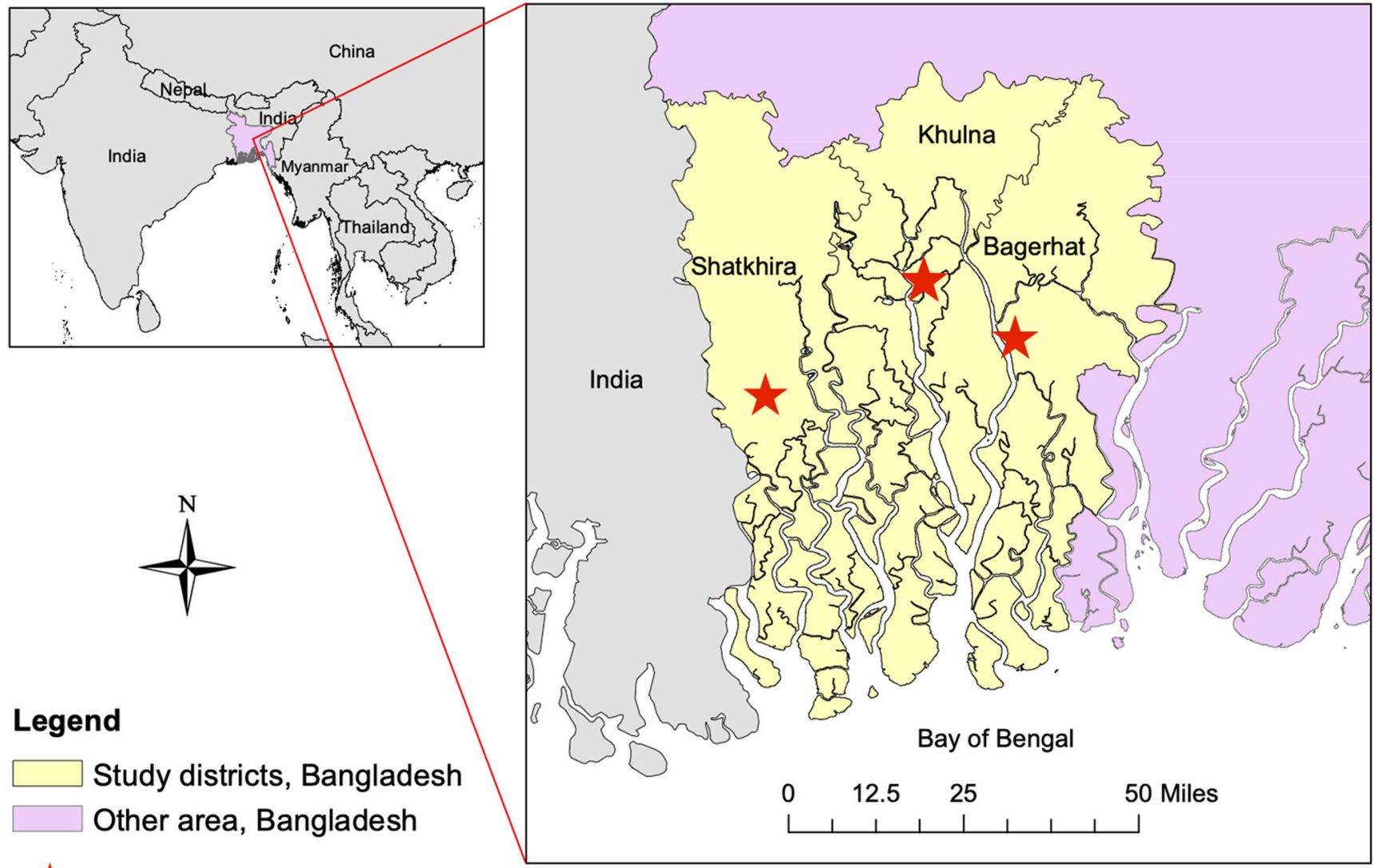

\section{Study sites}

Fig. 3 Map of study sites

\subsubsection{Community-level data collection}

Participants for community-level data collection were purposively selected to achieve a balance between males and females, geographic spread across the sites, and coverage of occupations and roles within the community. There were two rounds of community-level data collection, the first in May/June 2015 coinciding with hot season and the beginning of rainy season. Researchers recruited 25 households across the three sites and conducted a structured visit consisting of: interviews with both a male and female household member, a questionnaire, and salinity testing of the household's garden soil and sources of water. Household interviews covered the impacts of salinity on household food production and strategies for adapting, among other topics. Questionnaires assessed demographic characteristics and food production resources (land, gardens, ponds, livestock, etc.).

The research team also conducted six FGDs with other community members and interviewed ten community key informants across the three sites in May/June 2015. Among other activities, focus group participants discussed the impacts of salinity on food production, made seasonal calendars to depict trends in salinity and food production, and ranked and discussed adaptation strategies. Interviews with key informants focused on site history, salinity trends, and salinity impacts.

During the second round of community-level data collection in October 2015, coinciding with mid-to-late rainy season, the researcher team revisited all recruited households and conducted a follow-up interview with one household member to update information. Interviewees also participated in a rating exercise, whereby they were shown six pictures of factors cited in the literature or mentioned earlier by participants as a cause of salinity. Interviewees were asked about their awareness of the factor and the extent to which they believed it caused salinity.

\subsubsection{Salinity testing}

During community-level data collection, the team also tested the salinity of soil and water samples collected from the homestead gardens and sources of water used by recruited households (e.g., household and community ponds, tubewells, piped water sources). The team photographed the sources, marked GPS coordinates, recorded weather conditions, and asked participants questions about topics such as perceived 
levels of salinity and how the sources were used. Testing procedures were standard methods for assessing water and soil salinity (New South Wales Agriculture, 2000a, 2000b). All water testing happened on site, using an Extech EC500 pH/ conductivity meter to measure electroconductivity (EC) as the measurement of salinity. For soil, samples were collected and brought back to Dhaka. Testing involved the creation of a 1:5 soil-to-water suspension for each sample, measurement of the suspension's salinity $\left(\mathrm{EC}_{1: 5}\right)$ with a Hanna Instrument $86304 \mathrm{~N}$ electroconductivity meter, and the application of a conversion factor based on soil type to derive adjusted $\left(\mathrm{EC}_{\mathrm{e}}\right)$ from $\mathrm{EC}_{1: 5}$, as a measure of actual soil salinity. (A more detailed salinity testing protocol is available upon request.)

\subsubsection{Stakeholder-level data collection}

Stakeholder-level data collection took place in January and February 2016. The research team interviewed NGO and government representatives based in the southwest coastal region and Dhaka. The interviews entailed semi-structured discussion about impacts of salinity on agriculture and aquaculture and strategies for adapting, among other topics.

\subsection{Data analysis}

Salinity testing results were graphed and mapped. Household questionnaire results were tabulated. IDIs and FGDs were audio recorded, transcribed, and translated from Bangla to English. Initial interviews and follow-up interviews with household members lasted an average of 121 and $62 \mathrm{~min}$, respectively. FGDs, community key informant interviews, and stakeholder (NGO and government) interviews lasted an average of 162,132 , and 80 minutes, respectively.

Transcript analysis had three components: (1) coding illustrative quotes in MaxQDA software using a codebook developed from the key topics discussed; (2) extracting information from each transcript into a summary document using a standardized template (available upon request); and (3) writing memos about crosscutting themes and unexpected topics. Findings were synthesized by topic from the summary documents, then supplemented by quotes and ideas from the memos. All of the coding was conducted by the same researcher (the first author), as such inter-coder reliability was not calculated; however, the research team discussed results regularly and at key points to refine instruments (between the two seasons of community-level data collection and before stakeholder-level data collection).

\section{Results}

The research team conducted 59 IDIs with community members (including households and community key informants), and 6 FGDs with a total of 57 community participants. (See Table 4.) Twenty-five households were recruited. (See Table 5.) The team also interviewed 24 NGO representatives and 16 government officials. (See Table 6.)

\subsection{Severity of the salinity problem}

Testing of soil from homestead gardens in the hot season revealed that nearly all had salinity levels that would impair crop yields, many of these for a wide range of crops according to the United Nations Food and Agriculture Organization's soil salinity classification (Arbol et al., 1988). (See Fig. 4.) Salinity was particularly elevated amongst the Bagerhat and Satkhira samples, and lower, though not negligible, at the Khulna site. Relatively nearby locations (i.e., households within the same site) could have substantially different salinity readings (see supplementary information provided as Online Resource Figs. 1-3), though soil salinity levels were high overall. At the same time, salinity testing of groundwater and surface water sources revealed that the vast majority of the sources would be of limited utility for irrigating most crops in the hot season, according to guidelines for irrigation water quality (Ayers \& Wescot, 1985; Rao, 2006). (See Fig. 5.)

\subsection{Impacts of salinity on household food production}

\subsubsection{Crops and horticulture}

Salinity had profound impacts on household food production. While all households, save one, had one or more homestead gardens, interviews and field observations revealed that cultivation of fruits and vegetables was significantly hindered in the hot season, roughly March through June, due to salinity, along with heat and drought. The research team observed that many gardens lay completely or mostly fallow, vegetation was wilted and sparse, and soil was hard and dry. Community members said they could perceive increases in salinity because the earth would become powdery or crumbly, sometimes acquiring a whitish appearance, and seeds would not sprout. Only a few households attempted cultivation during these

Table 4 Community participants by gender and district

\begin{tabular}{llllllll}
\hline & \multicolumn{3}{c}{ In-depth interviews } & \multicolumn{3}{l}{$\begin{array}{l}\text { Focus group discussions } \\
\text { No. of FGDs (no. of participants) }\end{array}$} \\
\cline { 2 - 4 } \cline { 5 - 7 } District & Males & Females & Total & & Males & Females & Total \\
\hline Bagerhat & 10 & 9 & 19 & $1(7)$ & $1(15)$ & $2(22)$ \\
Satkhira & 11 & 10 & 21 & $1(7)$ & $1(11)$ & $2(18)$ \\
Khulna & 10 & 9 & 19 & $1(8)$ & $1(9)$ & $2(17)$ \\
Total & $\mathbf{3 1}$ & $\mathbf{2 8}$ & $\mathbf{5 9}$ & $\mathbf{3}(\mathbf{2 2})$ & $\mathbf{3}(\mathbf{3 5})$ & $\mathbf{6}(\mathbf{5 7})$ \\
\hline
\end{tabular}


Table 5 Profile of recruited households

\begin{tabular}{ll}
\hline Characteristic & $\begin{array}{l}\text { No. of households (out of } \\
25)\end{array}$ \\
\hline
\end{tabular}

$\begin{array}{ll}\text { District } & \\ \text { Bagerhat } & 8 \\ \text { Satkhira } & 9 \\ \text { Khulna } & 8 \\ \text { Female-headed household } & 2 \\ \text { Household size } & \\ 1-2 & 3 \\ 3-4 & 15 \\ 5-6 & 5 \\ 7+ & 2\end{array}$

Highest level of education attained by a household member

No formal education completed 3

Primary

10

Secondary

8

Post-secondary

4

Household religion

Muslim

17

Hindu

8

Primary occupation of household head

Agriculture

Aquaculture

Fish trading

Daily (wage) labor

Retired

Housing improvements reported

Electricity 4

Improved roofing (tiles, tin roof, etc.) 18

Improved sanitation facility (any kind of 25

latrine)

Land owned (other than land upon which dwelling is built)

$\begin{array}{ll}<0.10 \text { acre } & 8 \\ 0.10 \text { to } 0.49 \text { acre } & 4 \\ 0.50 \text { to } 0.99 \text { acre } & 4 \\ 1.0 \text { to } 1.9 \text { acres } & 5 \\ 2.0 \text { to } 4.9 \text { acres } & 3 \\ 5.0+\text { acres } & 1\end{array}$

months, sourcing water for irrigation from ponds farther away perceived as less saline, reserved rainwater, kitchen wastewater, or tubewells. Respondents detected salinity in some tubewells and ponds by the water's salty taste. A few households attempted irrigating with water as saline as 6000 to $7000 \mu \mathrm{S} / \mathrm{cm}$, despite levels in excess of 2500 to $3000 \mu \mathrm{S} / \mathrm{cm}$ already being considered too saline for irrigation use. The futility of attempting cultivation in the hot season, expressed by a man from Khulna, was echoed by many:
All of the plants died... If a farmer's crop dies before him, after being cultivated with a lot of toil and hard work, it is a matter of great agony.... We might have gotten a crop if there had been at least one rainfall. But there was no rain.

Most households recounted that salinity was less problematic two to three decades ago, and attributed rising salinity to the conversion of agricultural land to saltwater shrimp ponds and the seeping of retained saltwater into surrounding areas. Prior to this, rice cultivation was much more prominent, and vegetables and fruits were abundant and diverse. A few participants described fruit trees growing so thickly that one could "stand naked" by their house and not be seen from the road. Many community members echoed the following narrative, told by a woman from Khulna:

There was no salinity before the saltwater shrimp ponds were introduced. Crops grew a-plenty. My father-in-law told us a story about a time when there were many huge trees bearing jackfruit, lychee, rose apple, and more. All of these died when saltwater shrimp ponds were introduced.....Now, the land's fertility has declined due to salinity from the ponds. Crops don't grow well. We have to work hard and apply more fertilizers.... In the past, we didn't suffer this much.

Precipitation during rainy season, from June to October, helped to irrigate crops and dilute soil salinity, and this season was considered the most productive. However, too much rain - which occurred across all three sites the year data collection was conducted - could cause waterlogging and destroy crops. In winter, from October/ November to February, many households continued gardening by using their own ponds - which were less saline then-for irrigation. Many households reported that salinity hindered cultivation and obliged them to buy produce

Table 6 Stakeholder interview informants by institution

\begin{tabular}{ll}
\hline Institution & No. (out of 40) \\
\hline Government & 4 \\
Ministry of Agriculture & 2 \\
Ministry of Fisheries and Livestock & 3 \\
Ministry of Water Resources & 4 \\
Ministry of Environment and Forests & 3 \\
Ministry of Health and Family Welfare & \\
Non-governmental & 5 \\
Local/regional & 6 \\
National & 13 \\
International & \\
\hline
\end{tabular}




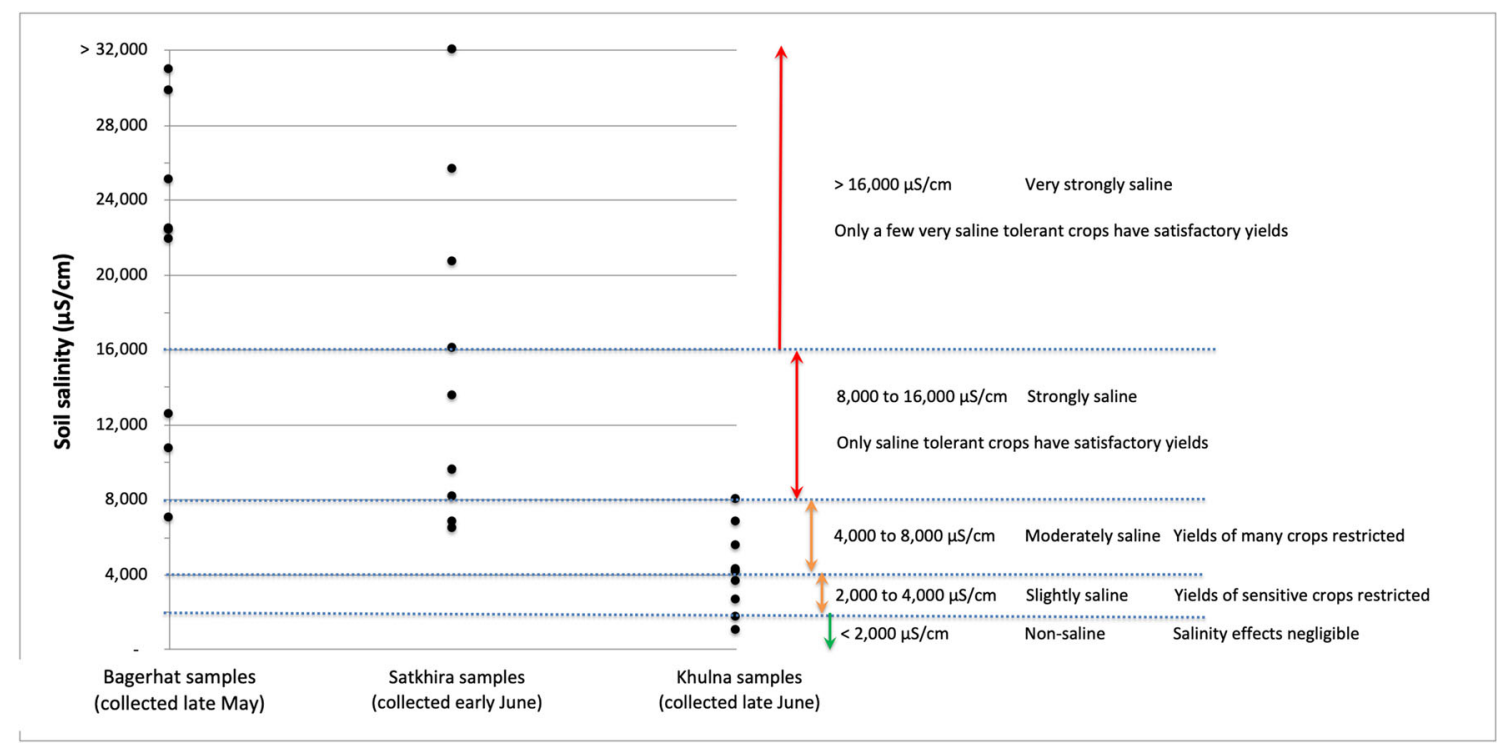

Fig. 4 Soil salinity results by site and soil salinity class, May-June 2015

from the market year-round, while a few families reported they were able to grow enough to eat and sell produce during winter and rainy seasons.

\subsubsection{Livestock and aquaculture}

Community members also reported that salinity made it much harder to raise animals. All households, save one, owned livestock at a small scale, with the most common being chickens and ducks, followed by cattle. Many reported giving up raising large ruminants because pastures had been rendered barren by salinity, especially during the hot season. As a woman from Bagerhat recalled:

In my childhood, I saw that almost everyone had a cow. Now there are no cows. Very few have them. What will the cows eat if [rice] paddy is not grown? If straw is not available?... Grass doesn't grow, so what will the cows eat?.... Everything is changing. Change means that now we don't have what we had before.
Fig. 5 Water salinity testing results by site and irrigation guidelines, June 2015

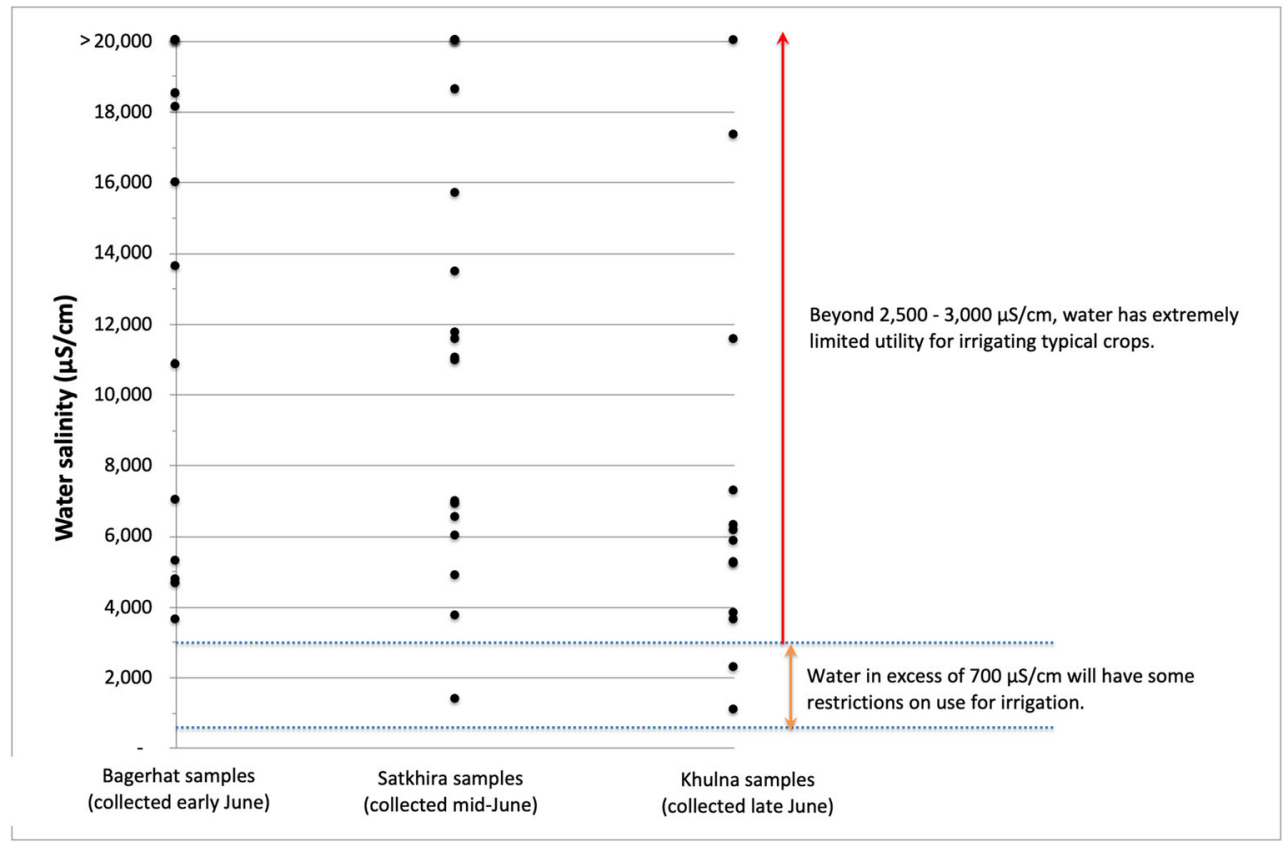


The use of manufactured feed was rare. To obtain feed like straw, grass, rise husks, and rice, most households from Bagerhat and Satkhira resorted to the market. Some families managed to pay caretakers to oversee their cattle in another less saline area for several months at a time. At the Khulna site, land was fertile enough so that households could procure feed materials from their own crop production or nearby pastures, rice fields, and mills.

A further challenge was obtaining drinking water for livestock. Animals were reported to drink saltwater often. A few households said their animals had adapted to drinking saltwater, but most reported that consumption of saltwater caused diarrhea, fever, gas, or convulsions in animals. Several respondents noted that more chemicals, such as pesticides and fertilizers, had been applied to the land because of salinity, and these chemicals triggered illnesses in animals. There were also reports that scarcity of freshwater and feed caused animals to be generally weak and more susceptible to disease.

Salinity also affected fish raised in homestead ponds and ghers, larger ponds enclosed by embankments constructed from the excavated soil. Nearly all households owned and/or rented land for aquaculture, but the area varied from less than a hundredth of an acre (360 square feet) to 5.6 acres. In general, salinity in the ponds and ghers was higher during the hot season and lower in the rainy season. Higher salinity had a significant impact on fish species diversity. Varieties of catfish, carp, tilapia, and other freshwater fish were reportedly more abundant in the past. These species were sometimes raised in less saline ponds or during rainy season, but died off when the water became too saline, as one farmer from Khulna lamented:

You would be stunned to see how my fish died. Today, I threw away another two fish. How large those fish were! One was a shoil and another a datina. The price of the two fish would have been 500 taka!

On the other hand, cultivation of bagda shrimp was possible in the higher salinity of saltwater ghers, and a few other species, such as golda shrimp, crab, mullet, and Asian seabass were described as somewhat saline tolerant. However, even saltwater fish died in the excessively high salinity levels reached during hot season. This included bagda, whose cultivation served as the primary motivation for converting land to saltwater ghers.

\subsubsection{Overall food security}

Community members felt less food secure due to salinity, not only because of the physical impact of salinity on crop production, livestock, and aquaculture, but also because of reduced economic opportunity. In hot season, men and women had fewer livelihood options, as agricultural activity-rice cultivation and gher aquaculture-declined. Males left the villages to find work, sometimes traveling to urban centers or to other rural areas with more agricultural production, while females who were equipped to do so engaged in nonagricultural activities. However, these options were reportedly not readily attainable or lucrative.

Families that were relatively successful in undertaking saltwater aquaculture in ghers could still experience food insecurity. One household from Satkhira, for example, earned 20,000 taka (about \$250 USD) per bigha of land (approximately a third of an acre) devoted to saltwater aquaculture, compared to 5000 taka per bigha when the land was previously used for rice plantation. Nonetheless, the household head emphasized:

The plants, trees, and fruits that grew in the past, they do not grow now. Does that give us peace? No. We don't have peace. We might have more money now, but in order to eat, we have to buy food.... Before, even though we made less money, we could grow food at home. We could also sell produce.

Moreover, produce purchased at the market was widely perceived to be poorer in quality than homestead-grown vegetables. Community members reported that market produce was ridden with insects or grown with fertilizers, thus offering less nutrition and making them sick.

Some respondents highlighted gender-based vulnerability in this context of food insecurity. Female respondents described how women fed their children before they could eat. Women in poorer households were forced to consume rotten food or leftovers that their families could not afford to throw away, leading them to suffer from diarrhea. An NGO representative in the area noted that women often had difficulties breastfeeding from being malnourished. Children were also described as malnourished, as a woman from Satkhira indicated:

Are you seeing how my children are underweight? We can't feed them adequately... We don't have enough [vegetable and fruit] cultivation to feed them well.... Look at their condition - their heads are big, but their bodies are thin, their arms and legs are thin.

\subsection{Responses to salinity and measures to adapt}

The near universal community perspective was that existing options for responding to salinity-including those undertaken with the household's own resources and interventions 
facilitated by outside governmental or non-governmental entities-were insufficient. Although saltwater aquaculture was considered by some NGO and government stakeholders to be an adaptation strategy and a form of economic development, community key informants and households viewed it as the biggest contributor to high salinity in their areas and a form of maladaptation. Instead, to community respondents, the most promising, but inaccessible, adaptation was improved irrigation. Other measures were discussed and observed in the field, including special cultivation techniques and salinetolerant plants, but were deemed to have limited effectiveness. The prospect of encouraging non-agricultural livelihoods and/ or planned migration was met with skepticism from both community members and stakeholders, with only a few exceptions.

\subsubsection{The "role" of saltwater aquaculture?}

Saltwater aquaculture was portrayed as both an adaptation response to salinity and a cause of salinity. A common narrative from community members and stakeholders was that saltwater gher aquaculture-bagda farming, specificallystarted because there was 'natural' salinity in the area and few livelihood possibilities during hot season. The activity expanded for two reasons. First, bagda farming appeared to be a profitable endeavor, at least initially, because bagda was highly valued for international export. Second, even those farmers who wished to cultivate crops could not continue to do so, as salinity intruded from neighboring ghers onto their land. They either tried gher farming or leased their land to wealthier, larger-scale gher operators, who reportedly paid low rents, taking advantage of the fact that many landowners were smallholder farmers left with few options. As a woman from Satkhira described, in terms similar to many other accounts:

When ghers were introduced, people fought over it.... Those who had money and land, they started with the ghers, while those who didn't, we tried to continue rice farming. Afterwards, we observed that saltwater infiltrate [into our land], and rice didn't grow. After two to three years of loss, we started going ghers... I didn't have any rice production, I was having losses. I tried to argue [with the gher owners], but still they wouldn't stop. So I couldn't fight it anymore. I had to go along with it and do the same thing with my land.... That is how gher farming started.

As bagda farming expanded and became the predominant activity year-round, gher operators deliberately brought in saltwater, exacerbating salinity. Amongst our study participants, saltwater gher aquaculture was widely seen as enriching the wealthy while rendering the poor more vulnerable, due to less subsistence production, fewer opportunities for land-poor peasants to work as daily laborers in agriculture, and economies of scale that could only be reaped with largerscale gher farming. The sentiment expressed by a daily laborer whose household was effectively landless was widely shared by many community members in our study:

Our small parcels of land are not productive... Poor people are in danger.... Our area has become totally saline, and thus, we, the poor, have to pay the cost of this. There is much harm to us.

Communities and stakeholders took strong stances on whether saltwater aquaculture should be promoted or prevented as a response to the current salinity situation. At the community level, the predominant view, supported by poorer and modestly situated households, was that saltwater gher aquaculture should be curtailed given its social and ecological consequences. Eliminating ghers and closing sluice gates to prevent saltwater from entering would allow the land to restore itself to lower salinity levels over several rainy seasons. Residents at the Khulna site especially emphasized this: a hard-won local prohibition of saltwater shrimp farming in 2009 had reportedly improved soil fertility and agricultural production over subsequent years.

The community perspective that saltwater gher aquaculture should be eliminated went hand-in-hand with both their observation that government intervention would be required and skepticism that this would happen. The government at the national and local levels, including leaders, were said to benefit from the saltwater aquaculture industry. As a man from Satkhira described:

It's true that we are increasing the salinity here by doing ghers. The government has declared this area, Satkhira District, for the fishery industry, an industrial area for cultivating bagda. Due to the business of the ghers, it's not possible to stop. As this is an industrial zone with millions of taka going out, it's not possible to stop it now. It's like they are robbing us. We are struggling to survive, but the government isn't conscious of that.

Participants cited examples from the past when advocacy and organizing to stop the entry of saltwater met with repressive and illicit responses from those supporting it. Many viewed their situation as hopeless, as one farmer put it: "If you bind the four legs of a cow and then slaughter it, what could the cow do then? Our situation is the same."

Communities' lack of confidence in government intervention could be understood in light of the mixed responses 
obtained from government stakeholders. Not only was there no coherent stance on saltwater aquaculture, but there was strong disagreement amongst government respondents as to whether salinity was even impacting the region. For example, the Ministry of Fisheries took issue with the characterization of salinity as a "problem" and celebrated saltwater shrimp farming as a great success for the region's inhabitants. As one of its representatives insisted, "The air is salty, the water is salty, the soil is salty. Everywhere, there is salinity. How could you prevent it?" Moreover, salinity was not a "curse," but a "gift," because it could be harnessed for saltwater shrimp farming. Ministry officials claimed that inhabitants of the region were coping successfully with salinity; those with difficulties were migrants from other regions or landless. One Ministry official accused NGOs of falsely portraying salinity as a problem and claiming that people were vulnerable in order to secure donor funding, which they pocketed for their own benefit.

On the other hand, one Ministry of Agriculture representative refused to consider saltwater aquaculture an adaptation option, stating, "Promoting shrimp cultivation in saline water? I don't even want to consider it an option.... We're fighting against saline water." Others, including the Ministry of the Environment and some NGO representatives, maintained that from a "pragmatic perspective, you couldn't get rid of commercial shrimp farming" because of its economic importance, and suggested that it could be done in an environmentally sustainable way through strategies such as zoning, land management, or replacing saltwater with freshwater species.

However, across the NGO and government sectors, a clear finding that emerged was the challenge of governance, including not only the enforcement of regulations like buffer zones, but also confusion over where responsibility lay. Officials from the Ministry of Agriculture and Ministry of Water's Water Development Board asserted that the government could do nothing to stop saltwater aquaculture, with the former adding that "gher owners were more powerful than the government" and the latter stating that it was up to "the people" to do it. There was also disagreement over who had control over the sluice gates. Many community members and NGO representatives said that the Ministry of Water had ultimate oversight over the entire coastal ecosystem through their authority over the embankment system, while the Ministry of Water officials maintained that they had a limited role because sluice gates were controlled by politically appointed committees.

\subsubsection{Options for adapting agriculture}

Various strategies for adapting cultivation to saline environments were described, such as improved irrigation, fertilizers, elevating the land, raised beds, vertical horticulture, and saline-tolerant plants. Amongst these, community members most emphasized irrigation with freshwater as pivotal but currently inaccessible. Their main message was that access to freshwater would make crop production possible; without it, no other technique would be sufficient. Respondents highlighted the need for new water infrastructure. Most households had no rainwater-harvesting tanks, their ponds were too small to maintain a supply of water through hot season, and they did not have a way to insulate their ponds from salinity. Scarcity meant prioritizing any available freshwater for drinking. When asked about irrigation, many community members responded: "We can't even manage having freshwater to drink; how could we manage freshwater for irrigation?"

A larger-scale intervention for improved irrigation was proposed by some, whereby silted ponds, canals, or rivers would be excavated and used to store rainwater. The infrastructure would need to include water transport from reservoirs to individual homesteads and croplands, as well as protect against infiltration from nearby bodies of saltwater. The latter point reinforced the idea, expressed by many community members, that permanent access to freshwater would require eliminating saltwater ghers.

Next to improved irrigation, fertilizers featured prominently amongst methods to adapt cultivation to a saline environment. Around our study sites, chemical fertilizers such as urea, sulfate, gypsum, potash, diammonium phosphate (DAP), and triple superphosphate (TSP) were used. However, their success in reducing salinity was reportedly mixed, and moreover they were considered harmful to consume and costly. As a woman from Satkhira recalled:

\section{My husband planted rice for two years but did not suc- ceed... The agricultural officers suggested applying sul- fate, gypsum, potash, and urea. They suggested many other fertilizers, which I can't name. We used every- thing. The rice didn't grow. When we went to talk to the officers again, they suggested more fertilizers. We followed their advice. After that, our pockets were emp- ty, and we didn't go to the agriculture office again. How do they expect the poor to have so much money?}

Another method for improving cultivation was to raise the land, ideally by at least two feet using fresh soil. Elevating the land could happen at various scales: a garden or homestead, an entire village, or beyond. To raise a homestead or garden was cost- and labor-intensive, and fertilizers and irrigation were still considered necessary. Moreover, soil could become salinized or plant roots could eventually reach saline soil. To raise land at the village level and beyond, government intervention was required. A project known as Tidal River Management was being undertaken by the Ministry of Water, which used sluice gates to promote land accretion in lowland areas, elevating and filling them with fertile silt, which could then be used for agriculture. Some informants reported, however, that 
gher operators had attempted to obstruct Tidal River Management projects.

Saline-tolerant plants, particularly crop varietals bred to be saline-tolerant, featured prominently in discussions with government officials and some NGOs. Varietals of cereals (rice and wheat) and vegetables (eggplant, tomato, and pumpkin) were being researched by the Ministry of Agriculture. Although viewed as promising by stakeholders, there was doubt that technology could keep pace with rising salinity. Current saline-tolerant rice varietals survived up to 10,000 to $12,000 \mu \mathrm{S} / \mathrm{cm}$, at most, and further progress was needed. Various stakeholders referenced an additional challenge - the time needed to pilot and scale up a varietal, which could take several years, during which time salinity could increase beyond the varietal's tolerance. As one representative of an international development non-profit explained:

The degree of salinity that used to exist might have been 12,000 or $13,000 \mu \mathrm{S} / \mathrm{cm}$.... after that, this might become double-15,000, 16,000, 20,000, or 40,000 $\mathrm{SS} / \mathrm{cm}$ in many places.... There are saline tolerant [rice] varieties, but we've seen that it takes four or five years to [do a] demonstrat [ion project] of one.... By that time, salinity has increased. The varietal was suitable for 13,000 $\mu \mathrm{S} / \mathrm{cm}$. Now it is not growing.... In fact there is no use for it. This is a very big hurdle.

We observed less familiarity with saline-tolerant varietals at the community level at our study sites: some households described selecting plants that could naturally withstand higher salinity, but very few had experience with salinetolerant hybrid varietals of rice or other crops. Some NGOs distributed or sold seeds and saplings, but households noted mixed success cultivating them and distrust in seed vendors. Several households with no experience with salt-tolerant varietals expressed willingness to try them, though continued to stress that rain or improved irrigation was crucial. A further issue was the use of chemical inputs needed to cultivate these varietals, which triggered concerns about costs and potential health impacts.

At the community level, an overall finding was that external NGO or government assistance to improve household food production was uncommon. Many households did practice special cultivation methods, using their own resources and sometimes copying ideas from neighbors. Methods included mixing organic matter with soil, putting soil in jute sacks or Styrofoam and plastic containers, and raising soil beds to help preserve freshwater content. (See supplementary information provided as Online Resource Figs. 4-7.) Such innovations were reportedly somewhat effective, albeit for a few plants at a time.

\subsubsection{Non-agricultural livelihoods and migration}

Among NGO and government stakeholders, the options of non-agricultural livelihoods and migration received much less support than the other strategies. However, these options were already being adopted, at least seasonally. As one villager observed:

\section{People go wherever they can find work. They are going, they are coming home, and they are leaving again. They return during vacation. This is what has been going on.... They are making their earnings elsewhere. If they sit at home, no one will feed them.}

In terms of rural-to-urban migration, some households reported that the males went to port areas to work on shipyards or to Dhaka to work as rickshaw pullers. However, various participants described more permanent migration or relocation of the entire household as undesirable, given their uneducated and impoverished status. They believed they would be illequipped to find work or navigate urban areas, at least without NGO or government assistance.

At the NGO and government level, rural-to-urban migration was widely disfavored as an adaptation strategy. The main justification was that it would exacerbate overcrowding in cities. There were also concerns about the ability of rural inhabitants to adapt, and about who would remain to continue agricultural production in the coastal region. A few stakeholders supported the development of non-agricultural or off-farm livelihoods, such as fish and food processing, but overall the emphasis was on keeping the population where it was and not undertaking actions that could encourage migration. Only one stakeholder, from a grassroots NGO, questioned the long-term role of agriculture in the country's economy in light of environmental change: "Adaptation is very much needed, no doubt, but at the same time we should transition to economic activities that are not dependent on the climate."

\section{Discussion}

This study illustrates how household food production is a multifaceted cornerstone of rural livelihood and food security in the southwest coastal region, and virtually every component of it is being affected by salinity. Our research expands upon previous work, which documents some of the impacts of salinity on food production in the region. These include declines in crop production (Miah et al., 2004; Rabbani et al., 2013); reduced agricultural diversity across rice, vegetable, and fruit tree species (Gain et al., 2007; Miah et al., 2004; M. H. Rahman et al., 2011a); and difficulties in managing livestock 
feed and animal health (M. H. Rahman et al., 2011b). In recent years, researchers and governmental and non-governmental organizations have proposed various projects to help farmers cope with salinity. Strategies have included saline-tolerant crop varietals (Abedin \& Shaw, 2013; Alam et al., 2013; Braun \& Saroar, 2012; CARE, 2006; Climate Change Cell, 2009; Shammi et al., 2016; WorldFish, 2014), modifications of cultivation systems (Abedin \& Shaw, 2013; Braun \& Saroar, 2012; CARE, 2006; M. A. Islam et al., 2018; Nandy et al., 2013; M. M. Rahman \& Islam, 2013; Shammi et al., 2016; WorldFish, 2014) and shifts to different livestock and plant species (Abedin \& Shaw, 2013; Alam et al., 2013; CARE, 2006; M. M. Rahman \& Islam, 2013; WorldFish, 2014). However, while making a compelling case about the impact of salinity, the existing literature provides less insight into what is required for implementation of these agricultural adaptations and the extent to which they fulfill intended objectives. There has been a call for more implementation research that evaluates agricultural interventions in the context of socio-economic, political, and environmental conditions, in order to better understand pathways to nutrition and other outcomes (Fiorella et al., 2016). Our study, though not focused on evaluating an outcome, begins to elucidate diverse challenges encountered along these pathways.

In contributing to the literature, our findings suggest that salinity adaptation efforts have been limited in their uptake and effectiveness, and highlight issues of access, equity, and governance as principal concerns. On the one hand, there are small-scale, low-cost innovations that households have devised themselves, such as raised beds and growing plants in makeshift containers, but these are useful for only a fraction of their cultivation. On the other hand, innovations perceived to be more promising and enduring, such as restricting saltwater aquaculture, improved irrigation, and large-scale elevation of cropland, are unattainable because of the scope of initiative and resources required. Despite salient challenges with food production, especially in the hot season, community respondents overwhelmingly described assistance or visits from government and NGO workers as uncommon.

As environmental and climatic changes continue and bring along associated vulnerabilities, the community of organizations addressing food security in Bangladesh will need to increasingly grapple with salinity. The development of infrastructure for irrigation warrants special attention. Historically, the goal of national self-sufficiency in the production of food grains, especially rice, was the driver behind the development of irrigation technologies, the expansion of irrigated areas, and the intensification of crop production in Bangladesh (M. W. Rahman \& Parvin, 2009; Zahid \& Ahmed, 2006). Our research builds on existing studies making the case for the importance of irrigation as a response to salinity, not just at the national level and for food grain production, but also at the community level and for homestead food production. Our study communities emphasized the importance of improved irrigation above all other adaptation strategies. However, few households had the means to irrigate their crops during the months when irrigation was most necessary, as an adequate groundwater supply was generally unavailable and most families could not afford increasing their freshwater storage capacity. Our findings resonate with a survey conducted by Jodder and colleagues, in which 100 Khulna-based farmers reported that lack of freshwater for irrigation near their cultivated areas was the biggest obstacle they faced in addressing salinity, and lack of NGO and government support was a significant problem (2016).

In the development of irrigation infrastructure, there are important environmental prerequisites - such as ensuring that water quality is not compromised by arsenic and other contaminants (I. M. M. Rahman \& Hasan, 2007) and preventing excessive groundwater depletion which can exacerbate lateral saltwater intrusion (Zahid \& Ahmed, 2006). Along with these technical and sustainability considerations, governance and equity should also be centered early on. In this connection, a recent study conducted in eight villages in Bagerhat and Satkhira districts found widespread community endorsement of irrigation to improve livelihoods, but serious weaknesses in existing irrigation schemes: irrigation was costly, such that agriculture was not profitable; irrigation required pumps (and sometimes tubewells), creating disparities between those who could afford the infrastructure and those who could not; and water management was encumbered by the manipulation of sluice gate infrastructure (Bernier et al., 2016). The researchers thus concluded that irrigation expansion should be prioritized only after water governance and equity were ensured.

Our study, which likewise reveals complexities in access and governance over water resources, underscores this point. The resource-intensive nature of improving irrigation implies the involvement of various external actors. Bangladesh's government has supposedly prioritized the southwest coastal region for investment in irrigation expansion (Bernier et al., 2016). Yet interviews with the Ministry of Agriculture and the Ministry of Water suggest that systematic efforts to excavate silted ponds, rivers, and canals to create reservoirs for holding rainwater are still incipient. It is not clear how much area can be cultivated with water stored in these excavated reservoirs and how well they can be insulated from salinity. A plan to deliver water and ensure access at the village or household level appears even more inchoate. Many questions as to the eventual beneficiaries of expanded irrigation infrastructure and mechanisms for equitable allocation and conflict resolution, among others, still need to be answered. These questions should be placed at the forefront of designing initiatives, in order to prevent the day-to-day and long-term collective action challenges that have affected drinking water systems in the southwest coastal region (M. B. Hasan et al., 2020; 
Lam et al., 2018), and which would likely arise in this context, as well. While more evidence is needed, Dewan (2020) suggests that there is potential for an excavation project of this sort-if designed bottom-up with local government officials, community members, and NGO staff-to be successful in providing both income to coastal inhabitants for the labor of excavation and water resources for public fishing and irrigation use. A detailed investigation into modes of community/ participatory resource management is beyond the scope of our study, but in line with prior research caution is urged against assuming that greater 'participation' will lead per se to more desirable or equitable results (Sovacool, 2018). The lack of consensus we observed over the locus of water management authority resonates with more in-depth studies on unsuccessful attempts to make management regimes in the region more 'depoliticized,' 'decentralized,' and 'participatory' (Dewan et al., 2015; Mutahara et al., 2020).

In recent years, an expanded notion of food security, beyond national sufficiency in food grain production, has helpfully inspired more research on homestead food production and determinants of household food security in rural Bangladesh (Belton, 2016; M. K. Hasan et al., 2018; Szabo et al., 2016b). There has also been some investigation into the factors correlated with agricultural adaptation in the context of a changing environment (Anik et al., 2018; Habiba et al., 2012; Sarker et al., 2013). These studies, along with our findings, point toward the need for implementation research that assesses socio-economic circumstances as mediating factors for adaptation uptake and food security.

For example, a 2018 study of the adoption of climate-smart agriculture (CSA) methods in south-central coastal Bangladesh assumed that the methods in questionincluding saline-tolerant crops, rainwater-harvesting, and other special cultivation methods-were not capital- or knowledge-intensive and therefore "within the reach of smallholder farmers" (M. K. Hasan et al., 2018). The study found a bivariate correlation between the number of CSA practices adopted and household food security, but concluded, also from bivariate correlations, that other characteristics (personal education, pond size, cattle ownership, and market access) had larger effects on food security. Our study suggests that the assumption of accessibility (i.e., that adaptation strategies are 'within reach') should be questioned, and that these characteristics and other socio-economic conditions should be interrogated as barriers/facilitators of adaptation. Szabo et al., which found that the negative association between soil salinity and household food security in the southwest coastal region was rendered not statistically significant after adjusting for household wealth, provides further support for this hypothesis (2016). Across our study sites, capital and labor were frequently referenced in discussions about actions that could be taken to address salinity - from hiring laborers to help a household elevate its homestead, to traveling to a less saline- affected area to graze animals and fetch water, to affording rainwater-harvesting infrastructure, feed materials, and other agricultural inputs.

The consideration of socio-economic contexts will be crucial for future implementation research on a strategy that has received particular attention in the development literature: transitioning to freshwater shrimp aquaculture. Our results and many other studies support the characterization of bagda farming as a form of maladaptation driving further salinization (Ali, 2006; A. F. M. T. Islam et al., 2011; M. A. Islam et al., 2019; Jodder et al., 2016; Johnson et al., 2016; Paul \& Vogl, 2011; Sohel \& Ullah, 2012), as well as inequality (Paprocki, 2018; Paprocki \& Cons, 2014). As the Khulna community recounted, a moratorium on saltwater shrimp farming enacted several years prior had restored the land by lowering salinity levels. Our soil testing results, though potentially affected by the timing of testing (i.e., an early start to the rainy season that coincided with our visit), nonetheless showed significantly lower salinity levels in Khulna just a couple weeks after the other sets of results. Accordingly, the replacement of bagda aquaculture by freshwater golda prawn cultivation is now being actively promoted by experts (M. H. Rahman et al., 2011a; M. M. Rahman et al., 2013; Sohel \& Ullah, 2012) and at least two of the NGOs we interviewed. Researchers have pointed to golda cultivation as a promising "environmentally-friendly" adaptation strategy that has been successful in other Asian countries (M. H. Rahman et al., 2011a).

Belton (2016) and Faruque et al. (2017) conducted case studies in Khulna and Bagerhat districts, respectively, in which they compared a village with golda farming to one with bagda farming, and found that the former, which allowed for mixed rice-prawn-fish cultivation, seemed to provide greater well-being, food security, and nutrition security. However, researchers have also noted that golda are relatively capitalintensive, as they feed on larger food items than bagda do and require supplementary feed (Belton, 2016; Johnson et al., 2016). While Belton found that gains from freshwater prawn production were distributed relatively equitably at the village level (Belton, 2016), Johnson et al. (2016) concluded otherwise from conducting a geospatial analysis to examine salinity, shrimp farming, and poverty at the union level. In analyzing unions in the southwestern and south-central coastal zones, Johnson et al. deduced that both types of aquaculture might produce economic benefits for intermediaries and external investors, but not for the poor and marginalized. The takeaway from this work and ours is that equity needs to be a deliberate and key part of the promotion of 'eco-friendly shrimp farming' as an adaptation strategy, as do issues of governance that will likely arise in a transition away from saltwater aquaculture.

Lastly, it is worth highlighting how our findings, which seek to provide socio-economic context for agricultural interventions to address salinity, simultaneously echo the 
cautionary conclusions of recent critical scholarship on climate change adaptation and development. These studies, many of which have unsurprisingly focused on Bangladesh, link adaptation and development efforts to such consequences as increasing socio-economic disparities, fueling agrarian dispossession, and exacerbating existing environmental problems (Dewan, 2020; Paprocki, 2018, and Sovacool, 2018). Sovacool's investigation into the political ecology of climate adaptation in Bangladesh, for example, documented processes of rural and urban land-grabbing by elites ("enclosure"), majoritarian and authoritarian decision-making ("exclusion"), degradation of environmental commons ("encroachment"), and further disempowerment of marginalized groups ("entrenchment") in the design and implementation of various national and coastal adaptation policies (Sovacool, 2018). The aggravation of risk and human insecurity caused by these processes should, Sovacool notes, serve as a "wakeup call for Bangladeshi planners that they can no longer ignore the broader social and political environment in which they operate" (Sovacool, 2018, p. 192). Indeed, that study, our study, and other similar work cited in a 2019 IPCC special report all reinforce the IPCC's own recommendation to "recognise the political nature of adaptation and explicitly address vulnerability and equity implications to achieve enduring, enabling impact of responses" (Oppenheimer et al., 2019, p. 408).

\section{Limitations}

At the community level, our study design incorporated ethnographic methods employed over two rounds of data collection. This level of engagement enhanced rapport with participants and confidence in the credibility of our results, which was important given that some of the topics of discussion were politically sensitive. However, it also limited the number of sites and households that we could select, given time and resource constraints. For this reason, we triangulated information with a number of key informants and stakeholders. Additional localities in the southwest coastal region and other salinity-affected deltaic regions warrant study, especially before the design and implementation of programs that should, in any case, account for site-specific social and environmental characteristics.

Further, with respect to salinity testing, unfortunately we were only able to conduct salinity testing at one point in time (during one season), as there were security concerns that coincided with the window we had available to sample soil in a subsequent season. Our testing results together with the qualitative data help make the case for the severity of the problem, but given the nature of our sampling, we cannot draw any conclusions about trends or between-season variation. Sampling more locations over several seasons/years would be recommended to create a more complete picture of salinity, including month-to-month trends, year-to-year changes, and spatial variation.

Finally, we recognize that food security has four pillarsavailability, access, utilization, and stability - all of which can be affected by the climate and environmental factors discussed in this study. Here we focused primarily on the pillar of 'availability,' through the lens of rural household food production, and had a few findings relevant to, but not an explicit focus on, access and stability. Further work on all four pillars is needed.

\section{Conclusions}

This research strengthens the case that salinity in Bangladesh's southwest coastal region poses a substantial threat to food production requiring adaptation, and sheds new light on the gaps between the current solutions being implemented and the problems salinity-affected communities continue to experience. Salinity affects multiple spheres of household food production, including homestead gardening, livestock rearing, and aquaculture. There are a range of adaptation strategies being proposed, negotiated, and undertaken, but effective adaptation remains a critical challenge. Our research highlighted issues of equity, accessibility, and governance as important considerations for organizations facilitating adaptation, as well as the need for implementation research that considers socio-economic, political, and environmental contexts to evaluate intervention pathways to improved food security and nutritional status. Moreover, ecologic approaches to desalinization-which will necessitate restrictions on land uses that exacerbate salinity - are strongly recommended. In this regard, salinity in the southwest coastal region is a case study of how successful adaptation to the limits of our physical world will likely require removing political economic barriers to good environmental stewardship, while advancing solutions that center the needs of the most socially vulnerable.

Supplementary Information The online version contains supplementary material available at https://doi.org/10.1007/s12571-021-01177-5.

Acknowledgements We thank the study participants for their generous time and insights, colleagues at the International Centre for Diarrhoeal Disease Research, Bangladesh for their invaluable advice, and Professors Robert Lawrence and Katalin Szlávecz at Johns Hopkins University for lending their expertise to this research. We are also especially thankful to Afsana Sharmin and Abdul Matin at icddr,b, who worked tirelessly and astutely as the core researchers of the data collection team.

Funding This work was supported by the Johns Hopkins Center for a Livable Future-Lerner Fellowship, the Johns Hopkins Environment, Energy, Sustainability \& Health Institute, and the Johns Hopkins Center for Qualitative Studies in Health and Medicine. 


\section{Declarations}

Ethics approval The study was approved by the Institutional Review Board of Johns Hopkins Bloomberg School of Public Health, and the Research and Ethics Review Committees of the International Centre for Diarrhoeal Disease Research, Bangladesh (icddr,b).

Consent Written consent was obtained from all study participants.

Conflict of interest The authors have no conflicts of interest to declare.

Open Access This article is licensed under a Creative Commons Attribution 4.0 International License, which permits use, sharing, adaptation, distribution and reproduction in any medium or format, as long as you give appropriate credit to the original author(s) and the source, provide a link to the Creative Commons licence, and indicate if changes were made. The images or other third party material in this article are included in the article's Creative Commons licence, unless indicated otherwise in a credit line to the material. If material is not included in the article's Creative Commons licence and your intended use is not permitted by statutory regulation or exceeds the permitted use, you will need to obtain permission directly from the copyright holder. To view a copy of this licence, visit http://creativecommons.org/licenses/by/4.0/.

\section{References}

Abedin, M. A., \& Shaw, R. (2013). Agriculture adaptation in coastal zone of Bangladesh. In Climate change adaptation actions in Bangladesh (pp. 207-225). Springer.

Alam, M., Ahammad, R., Nandy, P., \& Rahman, S. (2013). Coastal livelihood adaptation in changing climate: Bangladesh experience of NAPA priority project implementation. In R. Shaw, F. Mallick, \& A. Islam (Eds.), Climate change adaptation actions in Bangladesh (pp. 253-276). Springer.

Ali, A. M. S. (2006). Rice to shrimp: Land use/land cover changes and soil degradation in southwestern Bangladesh. Land Use Policy, 23(4), 421-435. https://doi.org/10.1016/j.landusepol.2005.02.001.

Anik, A. R., Ranjan, R., \& Ranganathan, T. (2018). Estimating the impact of salinity stress on livelihood choices and incomes in Bangladesh. Journal of International Development, 30(8), 1414 1438.

Arbol, I. P., Yadav, J. S. P., \& Massoud, F. I. (1988). Salt-affected soils and their management. Food and Agriculture Organization of the United Nations.

Ayers, R. S., \& Wescot, D. W. (1985). Water quality for agriculture. Food and Agriculture Organization of the United Nations.

Bangladesh Bureau of Statistics. (2019). Preliminary report on Agriculture census 2019. Bangladesh Bureau of Statistics.

Bangladesh Ministry of Environment and Forests. (2015). Intended nationally determined contributions (INDC). Government of Bangladesh.

Belton, B. (2016). Shrimp, prawn and the political economy of social wellbeing in rural Bangladesh. Journal of Rural Studies, 45, 230 242. https://doi.org/10.1016/j.jrurstud.2016.03.014.

Bernier, Q., Sultana, P., Bell, A. R., \& Ringler, C. (2016). Water management and livelihood choices in southwestern Bangladesh. Journal of Rural Studies, 45, 134-145. https://doi.org/10.1016/j. jrurstud.2015.12.017.

Braun, M., \& Saroar, M. (2012). Participatory action research on climate risk management, Bangladesh. WorldFish.

CARE. (2006). The reducing vulnerability to climate change (RVCC) project: Final report. CARE Canada \& CARE Bangladesh.
Cisneros, B. E. J., Oki, T., Arnell, N. W., Benito, G., Cogley, J. G., Döll, P., et al. (2014). Freshwater resources. In C. B. Field, V. R. Barros, D. J. Dokken, K. J. Mach, M. D. Mastrandrea, T. E. Bilir, et al. (Eds.), Climate Change 2014: Impacts, Adaptation, and Vulnerability. Part A: Global and Sectoral Aspects. Contribution of Working Group II to the Fifth Assessment Report of the Intergovernmental Panel on Climate Change (pp. 229-269). Cambridge, United Kingdom and New York, NY, USA: Cambridge University Press.

Climate Change Cell. (2009). Adaptive crop agriculture including innovative farming practices in the coastal zone of Bangladesh. Department of Environment, Bangladesh Ministry of Environment and Forests.

Cramer, W., Yohe, G., Auffhammer, M., Huggel, C., Molau, U., da Silva Dias, M., et al. (2014). Detection and attribution of observed impacts. In C. B. Field, V. R. Barros, D. J. Dokken, K. J. Mach, M. D. Mastrandrea, T. E. Bilir, et al. (Eds.), Climate Change 2014: Impacts, Adaptation, and Vulnerability. Part A: Global and Sectoral Aspects. Contribution of Working Group II to the Fifth Assessment Report of the Intergovernmental Panel on Climate Change (pp. 979-1037). Cambridge, United Kingdom and New York, NY, USA: Cambridge University Press.

Cruz, R. V., Harasawa, H., Lal, M., Wu, S., Anokhin, Y., Punsalmaa, B., et al. (2007). Asia. In M. L. Parry, O. F. Canziani, J. P. Palutikof, P. J. van der Linden, \& C. E. Hanson (Eds.), Climate change 2007: Impacts, adaptation and vulnerability. Contribution of working group II to the fourth assessment report of the intergovernmental panel on climate change (pp. 469-506). Cambridge: Cambridge University Press.

Das, S., Chandra, H., \& Saha, U. R. (2019). District level estimates and mapping of prevalence of diarrhoea among under-five children in Bangladesh by combining survey and census data. PLoS One, 14(2), e0211062. https://doi.org/10.1371/journal.pone.0211062.

Dewan, C. (2020). "Climate change as a spice": Brokering environmental knowledge in Bangladesh's development industry. Ethnos, 1-22. https://doi.org/10.1080/00141844.2020.1788109.

Dewan, C., Mukherji, A., \& Buisson, M.-C. (2015). Evolution of water management in coastal Bangladesh: From temporary earthen embankments to depoliticized community-managed polders. Water International, 40(3), 401-416. https://doi.org/10.1080/02508060. 2015.1025196

Ericson, J., Vorosmarty, C., Dingman, S., Ward, L., \& Meybeck, M. (2006). Effective Sea-level rise and deltas: Causes of change and human dimension implications. Global and Planetary Change, 50(1-2), 63-82. https://doi.org/10.1016/j.gloplacha.2005.07.004.

Faruque, G., Sarwer, R. H., Karim, M., Phillips, M., Collis, W. J., Belton, B., \& Kassam, L. (2017). The evolution of aquatic agricultural systems in Southwest Bangladesh in response to salinity and other drivers of change. International Journal of Agricultural Sustainability, 15(2), 185-207. https://doi.org/10.1080/14735903. 2016.1193424

Field, C. B., Barros, V. R., Mach, K. J., Mastrandrea, M. D., van Aalst, M. K., Adger, W. N., \& others. (2014). Technical summary. In C. B. Field, V. R. Barros, D. J. Dokken, K. J. Mach, M. D. Mastrandrea, T. E. Bilir, et al. (Eds.), Climate Change 2014: Impacts, Adaptation, and Vulnerability. Part A: Global and Sectoral Aspects. Contribution of Working Group II to the Fifth Assessment Report of the Intergovernmental Panel on Climate Change (pp. 35-94). Cambridge, United Kingdom and New York, NY, USA: Cambridge University Press.

Fiorella, K. J., Chen, R. L., Milner, E. M., \& Fernald, L. C. H. (2016). Agricultural interventions for improved nutrition: A review of livelihood and environmental dimensions. Global Food Security, 8, 39 47. https://doi.org/10.1016/j.gfs.2016.03.003.

Food and Agriculture Organization of the United Nations. (2009). Situation assessment report in the southwest coastal region of 
Bangladesh. Food and Agriculture Organization of the United Nations (FAO) and Bangladesh Department of Agricultural Extension (DAE).

Gain, A. K., Aryal, K. P., Sana, P., \& Uddin, M. N. (2007). Effect of river salinity on crop diversity: A case study of southwest coastal region of Bangladesh. Nepal Agriculture Research Journal, 8, 29-37.

Global Nutrition Report. (2020). Country Nutrition Profile: Bangladesh. https:/globalnutritionreport.org/resources/nutrition-profiles/asia/ southern-asia/bangladesh/. Accessed 14 December 2020

Habiba, U., Shaw, R., \& Takeuchi, Y. (2012). Farmers' perception and adaptation practices to cope with drought: Perspectives from northwestern Bangladesh. International Journal of Disaster Risk Reduction, 1, 72-84. https://doi.org/10.1016/j.ijdrr.2012.05.004.

Haque, S. A. (2006). Salinity problems and crop production in coastal regions of Bangladesh. Pakistan Journal of Botany, 38(5), 13591365.

Hasan, M. B., Driessen, P., Zoomers, A., \& Van Laerhoven, F. (2020). How can NGOs support collective action among the users of rural drinking water systems? A case study of managed aquifer recharge (MAR) systems in Bangladesh. World Development, 126, 104710. https://doi.org/10.1016/j.worlddev.2019.104710.

Hasan, M. K., Desiere, S., D’Haese, M., \& Kumar, L. (2018). Impact of climate-smart agriculture adoption on the food security of coastal farmers in Bangladesh. Food Security, 10(4), 1073-1088. https:// doi.org/10.1007/s12571-018-0824-1.

Ishrat, F. (2013). Situation analysis for nutrition at the center. CARE Bangladesh.

Islam, A. F. M. T., Navera, U. K., \& Mahboob, M. G. (2011). Impact of brackish water shrimp farming on agricultural land and surrounding environment in the southwest coastal zone of Bangladesh. In Proceedings of the International Conference on Environmental Aspects of Bangladesh (pp. 112-114).

Islam, M. A., Akber, M. A., Ahmed, M., Rahman, M. M., \& Rahman, M. R. (2018). Climate change adaptations of shrimp farmers: A case study from southwest coastal Bangladesh. Climate and Development, 11(6), 459-468. https://doi.org/10.1080/17565529. 2018.1442807.

Islam, M. A., Hoque, M. A., Ahmed, K. M., \& Butler, A. P. (2019). Impact of climate change and land use on groundwater salinization in southern Bangladesh: Implications for other Asian deltas. Environmental Management, 64(5), 640-649. https://doi.org/10. 1007/s00267-019-01220-4.

Jodder, R., Haque, M. A., Kumar, T., Jahiruddin, M., Rahman, M. Z., \& Clarke, D. (2016). Climate change effects and adaptation measures for crop production in south-west coast of Bangladesh. Research in Agriculture Livestock and Fisheries, 3(3), 369-378. https://doi.org/ 10.3329/ralf.v3i3.30727.

Johnson, F. A., Hutton, C. W., Hornby, D., Lázár, A. N., \& Mukhopadhyay, A. (2016). Is shrimp farming a successful adaptation to salinity intrusion? A geospatial associative analysis of poverty in the populous Ganges-Brahmaputra-Meghna Delta of Bangladesh. Sustainability Science, 11(3), 423-439. https://doi. org/10.1007/s11625-016-0356-6.

Kabir, R., Khan, H. T. A., Ball, E., \& Caldwell, K. (2016). Climate change impact: The experience of the coastal areas of Bangladesh affected by cyclones Sidr and Aila. Journal of Environmental and Public Health, 2016, 1-9. https://doi.org/10.1155/2016/9654753.

Lam, Y., Surkan, P. J., Winch, P. J., \& Nizame, F. A. (2018). Freshwater access in high salinity regions: Impacts and adaptation insights from the Ganges River Delta. Journal of Global Health Reports, 8 , e2018007. https://doi.org/10.29392/joghr.2.e2018007.
Lázár, A. N., Nicholls, R. J., Hall, J. W., Barbour, E. J., \& Haque, A. (2020). Contrasting development trajectories for coastal Bangladesh to the end of century. Regional Environmental Change, 20(3), 93.

Miah, M. Y., Mannan, M. A., Quddus, K. G., Mahmud, M. A. M., \& Baida, T. (2004). Salinity on cultivable land and its effects on crops. Pakistan Journal of Biological Sciences, 7(9), 1322-1326.

Mutahara, M., Warner, J. F., \& Khan, M. S. A. (2020). Multi-stakeholder participation for sustainable delta management: A challenge of the socio-technical transformation in the management practices in Bangladesh. International Journal of Sustainable Development \& World Ecology, 27(7), 611-624. https://doi.org/10.1080/13504509. 2020.1722278

Myers, S. S., Smith, M. R., Guth, S., Golden, C. D., Vaitla, B., Mueller, N. D., Dangour, A. D., \& Huybers, P. (2017). Climate change and global food systems: Potential impacts on food security and undernutrition. Annual Review of Public Health, 38, 259-277.

Nandy, P., Ahammad, R., Alam, M., \& Islam, A. (2013). Coastal ecosystem based adaptation: Bangladesh experience. In R. Shaw, F. Mallick, \& A. Islam (Eds.), Climate change adaptation actions in Bangladesh (pp. 277-303). Springer.

National Institute of Population Research and Training (NIPORT) \& ICF International. (2020). Bangladesh demographic and health survey 2017-2018. NIPORT and ICF International.

New South Wales Agriculture. (2000a). Salinity notes no. 8: How to texture soils and test for salinity. New South Wales Agriculture.

New South Wales Agriculture. (2000b). Salinity notes no. 4: How do I test water salinity? New South Wales Agriculture.

Nishat, A., \& Mukherjee, N. (2013). Sea level rise and its impacts in coastal areas of Bangladesh. In R. Shaw, F. Mallick, \& A. Islam (Eds.), Climate change adaptation actions in Bangladesh (pp. 43 50). Springer.

Oppenheimer, M., Glavovic, B. C., Hinkel, J., van de Wal, R., Magnan, A. K., Abd-Elgawad, A., et al. (2019). Sea level rise and implications for low-lying islands, coasts and communities. In H. O. Portner, D. C. Roberts, V. Masson-Delmotte, P. Zhai, M. Tignor, E. Poloczanska, et al. (Eds.), IPCC Special Report on the Ocean and Cryosphere in a Changing Climate (pp. 321-445).

Paprocki, K. (2018). Threatening dystopias: Development and adaptation regimes in Bangladesh. Annals of the American Association of Geographers, 108(4), 955-973. https://doi.org/10.1080/24694452. 2017.1406330.

Paprocki, K., \& Cons, J. (2014). Life in a shrimp zone: Aqua- and other cultures of Bangladesh's coastal landscape. The Journal of Peasant Studies, 41(6), 1109-1130. https://doi.org/10.1080/03066150.2014. 937709.

Paul, B. G., \& Vogl, C. R. (2011). Impacts of shrimp farming in Bangladesh: Challenges and alternatives. Ocean \& Coastal Management, 54(3), 201-211. https://doi.org/10.1016/j. ocecoaman.2010.12.001.

Pukinskis, I. (2015). The polder promise: Unleashing the productive potential in southern Bangladesh. CGIAR Research Program on Water, Land and Ecosystems. https://wle.cgiar.org/sites/default/ files/documents/The\%20polder\%20promise_WLE.pdf

Rabbani, G., Rahman, A., \& Mainuddin, K. (2013). Salinity-induced loss and damage to farming households in coastal Bangladesh. International Journal of Global Warming, 5(4), 400-415.

Rahman, I. M. M., \& Hasan, M. T. (2007). Arsenic incorporation into garden vegetables irrigated with contaminated water. Journal of Applied Sciences and Environmental Management, 11(4), 105-112.

Rahman, M. A. T. M., Rahman, S. H., \& Majumder, R. K. (2012). Groundwater quality for irrigation of deep aquifer in southwestern 
zone of Bangladesh. Songklanakarin Journal of Science and Technology, 34(3), 345-352.

Rahman, M. H., Lund, T., \& Bryceson, I. (2011a). Salinity impacts on agro-biodiversity in three coastal, rural villages of Bangladesh. Ocean \& Coastal Management, 54(6), 455-468. https://doi.org/10. 1016/j.ocecoaman.2011.03.003.

Rahman, M. H., Lund, T., \& Bryceson, I. (2011b). Salinity effects on food habits in three coastal, rural villages in Bangladesh. Renewable Agriculture and Food Systems, 26(3), 230-242. https://doi.org/10. 1017/S1742170511000020.

Rahman, M. M., \& Bhattacharya, A. K. (2014). Saline water intrusion in coastal aquifers: A case study from Bangladesh. IOSR Journal of Engineering, 4(1), 07-13. https://doi.org/10.9790/3021-04170713.

Rahman, M. M., Giedraitis, V. R., Lieberman, L. S., Akhtar, T., \& Taminskiene, V. (2013). Shrimp cultivation with water salinity in Bangladesh: The implications of an ecological model. Universal Journal of Public Health, 1(3), 131-142.

Rahman, M. M., Hassan, M. Q., Islam, M. S., \& Shamsad, S. Z. K. M. (2000). Environmental impact assessment on water quality deterioration caused by the decreased Ganges outflow and saline water intrusion in South-Western Bangladesh. Environmental Geology, 40(1-2), 31-40.

Rahman, M. M., \& Islam, A. (2013). Adaptation technologies in practice and future potentials in Bangladesh. In R. Shaw, F. Mallick, \& A. Islam (Eds.), Climate change adaptation actions in Bangladesh (pp. 305-330). Springer.

Rahman, M. W., \& Parvin, L. (2009). Impact of irrigation on food security in Bangladesh for the past three decades. Journal of Water Resource and Protection, 01(03), 216-225. https://doi.org/10. 4236/jwarp.2009.13027.

Rahman, R., Ando, K., \& Takeda, S. (2014). Development of shrimpbased cropping systems in the coastal area of Bangladesh: A villagelevel study in Satkhira district. Journal of Land Use Science, 9(2), 195-210. https://doi.org/10.1080/1747423X.2013.786147.

Rao, N. S. (2006). Seasonal variation of groundwater quality in a part of Guntur District, Andhra Pradesh, India. Environmental Geology, 49(3), 413-429. https://doi.org/10.1007/s00254-005-0089-9.

Salehin, M., Chowdhury, M. M., Clarke, D., Mondal, S., Nowreen, S., Jahiruddin, M., \& Haque, A. (2018). Mechanisms and drivers of soil salinity in coastal Bangladesh. In R. J. Nicholls, C. W. Hutton, W. N. Adger, S. E. Hanson, M. M. Rahman, \& M. Salehin (Eds.), Ecosystem Services for Well-Being in deltas: Integrated assessment for policy analysis. Springer International Publishing. https://doi. org/10.1007/978-3-319-71093-8.

Sarker, M. A. R., Alam, K., \& Gow, J. (2013). Assessing the determinants of rice farmers' adaptation strategies to climate change in Bangladesh. International Journal of Climate Change Strategies and Management, 5(4), 382-403. https://doi.org/10.1108/ IJCCSM-06-2012-0033.

Sarwar, M. G. M., \& Islam, A. (2013). Multi hazard vulnerabilities of the coastal land of Bangladesh. In R. Shaw, F. Mallick, \& A. Islam (Eds.), Climate change adaptation actions in Bangladesh (pp. 121-141). Springer.

Shahid, S., Chen, X., \& Hazarika, M. K. (2006). Evaluation of groundwater quality for irrigation in Bangladesh using geographic information system. Journal of Hydrology and Hydromechanics, 54, 3-14.
Shammi, M., Karmakar, B., Rahman, M. M., Islam, M. S., Rahman, R., \& Uddin, M. (2016). Assessment of salinity hazard of irrigation water quality in monsoon season of Batiaghata Upazila, Khulna District, Bangladesh and adaptation strategies. Pollution, 2(2), 183-197.

Sohel, M. S. I., \& Ullah, M. H. (2012). Ecohydrology: A framework for overcoming the environmental impacts of shrimp aquaculture on the coastal zone of Bangladesh. Ocean \& Coastal Management, 63, 6778. https://doi.org/10.1016/j.ocecoaman.2012.03.014.

Soil Resources Development Institute. (2010). Saline soils of Bangladesh. Bangladesh Ministry of Agriculture.

Sovacool, B. K. (2018). Bamboo beating bandits: Conflict, inequality, and vulnerability in the political ecology of climate change adaptation in Bangladesh. World Development, 102, 183-194. https://doi. org/10.1016/j.worlddev.2017.10.014.

Szabo, S., Brondizio, E., Renaud, F. G., Hetrick, S., Nicholls, R. J., Matthews, Z., Tessler, Z., Tejedor, A., Sebesvari, Z., FoufoulaGeorgiou, E., da Costa, S., \& Dearing, J. A. (2016a). Population dynamics, delta vulnerability and environmental change: Comparison of the Mekong, Ganges-Brahmaputra and Amazon delta regions. Sustainability Science, 11(4), 539-554. https://doi. org/10.1007/s11625-016-0372-6.

Szabo, S., Hossain, M. S., Adger, W. N., Matthews, Z., Ahmed, S., Lázár, A. N., \& Ahmad, S. (2016b). Soil salinity, household wealth and food insecurity in tropical deltas: Evidence from south-west coast of Bangladesh. Sustainability Science, 11(3), 411-421. https://doi.org/ 10.1007/s11625-015-0337-1.

The World Bank \& US Geological Survey. (2010). Implications of climate change for fresh groundwater resources in coastal aquifers in Bangladesh. The World Bank.

US Environmental Protection Agency. (2016). Climate adaptation and saltwater intrusion. US EPA. Overviews and Factsheets. https:// www.epa.gov/arc-x/climate-adaptation-and-saltwater-intrusion. Accessed 14 April 2021

Werner, A. D., Bakker, M., Post, V. E., Vandenbohede, A., Lu, C., AtaieAshtiani, B., et al. (2013). Seawater intrusion processes, investigation and management: Recent advances and future challenges. Advances in Water Resources, 51, 3-26.

Wong, P. P., Losada, I. J., Gattuso, J. P., Hinkel, J., Khattabi, A., McInnes, K. L., et al. (2014). Coastal systems and low-lying areas. In C. B. Field, V. R. Barros, D. J. Dokken, K. J. Mach, M. D. Mastrandrea, T. E. Bilir, et al. (Eds.), Climate Change 2014: Impacts, Adaptation, and Vulnerability. Part A: Global and Sectoral Aspects. Contribution of Working Group II to the Fifth Assessment Report of the Intergovernmental Panel on Climate Change (pp. 361-409). Cambridge, United Kingdom and New York, NY, USA: Cambridge University Press.

WorldFish. (2014). Farms for the future: Climate smart farming in Bangladesh. WorldFish.

Zahid, A., \& Ahmed, S. R. U. (2006). Groundwater resources development in Bangladesh: Contribution to irrigation for food security and constraints to sustainability (IWMI books, reports no. H039306). International Water Management Institute. https://EconPapers. repec.org/RePEc:iwt:bosers:h039306 


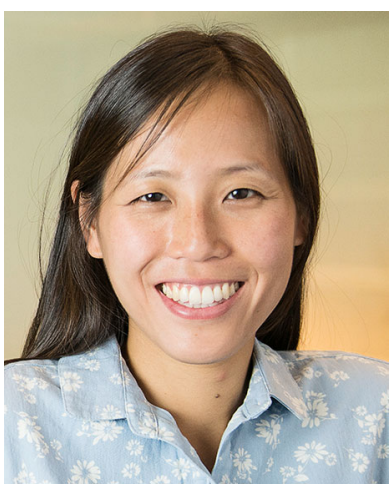

Yukyan Lam is a social and behavioral health scientist, working as a Staff Scientist at the Natural Resources Defense Council and an Associate in the Department of International Health at the Johns Hopkins Bloomberg School of Public Health. Her research is situated at the nexus of science and policy, and draws on quantitative and qualitative research methods, spatial analysis, and community partnerships. She is currently focused on addressing environmental justice, climate change, and the cumulative impacts of environmental and social vulnerability.

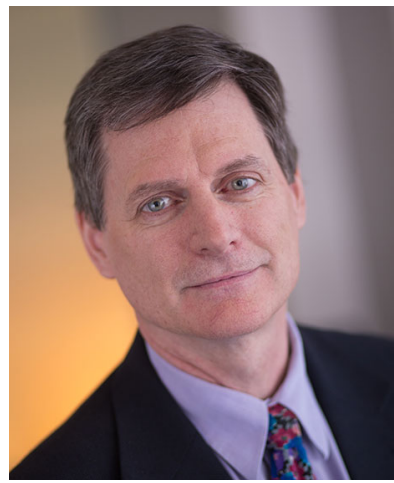

Peter J. Winch conducts research on community engagement in health, behavior change interventions, and qualitative and formative research. Current research includes 1) Behavior change interventions for infectious diseases, environmental sustainability, and water, sanitation and hygiene (WASH); 2) Interventions for facility and community-based health care providers to improve quality of assessment, treatment and adherence to testing and treatment recommendations; 3 ) Implementation of facility and community-based maternal, newborn and child health interventions, maternal mental health; and 4) Community and policy interventions to reduce greenhouse gases and criteria air pollutants.

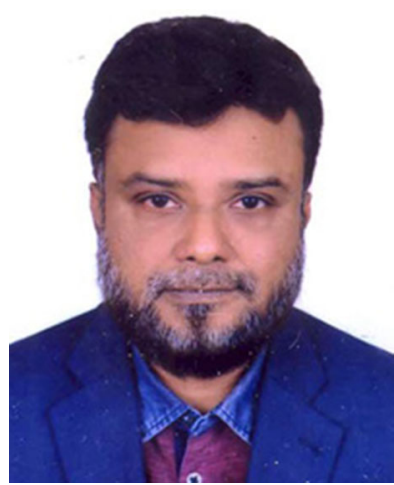

Fosiul Alam Nizame has conducted research for over a decade on interventions to reduce infectious disease burdens in Bangladesh. His work addresses food hygiene, including YIFC/ complementary feeding, WASH, environmental health, air pollution, and antimicrobial resistance in Bangladesh, through formative research, social and behaviour change communication, and intervention trials. Mr. Nizame's research uses both qualitative and quantitative methods, and has been published in numerous peer-reviewed journals.

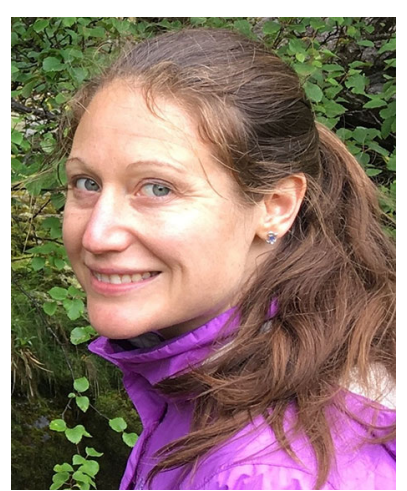

Elena T. Broaddus-Shea is a Senior Instructor in the University of Colorado School of Medicine's Department of Family Medicine. Her work examines food security and agriculturenutrition interventions in lowincome settings. Her current research focuses on implementation of programs to identify and address social determinants of health-related needs in primary care settings.

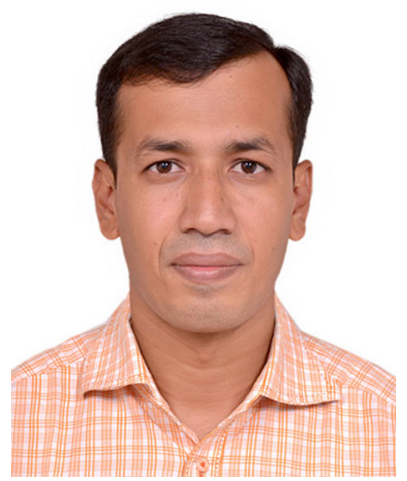

Md. Golam Dostogir Harun has conducted research for over a decade on emerging infections to reduce the infectious disease burden in Bangladesh. His work has focused on emerging infections, including infection prevention and control, antimicrobial resistance, infection surveillance, health workers and occupational safety, health systems, environmental health and air pollution. Mr. Harun draws on both qualitative and quantitative methods to implement and conduct research, and his work has been published in a number of peer-reviewed journals.

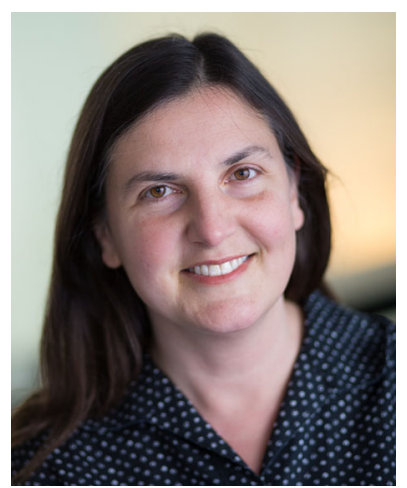

Pamela J. Surkan is a social epidemiologist who conducts crossdisciplinary research to understand how a wide variety of social and social-environmental exposures affect health. Much of her research has focused on examining interactions between social conditions and other factors that impact health, such as dietary behaviors and environmental exposures. She uses qualitative, quantitative, and mixed methods studies to aid in the development and implementation of interventions targeting underserved populations both in the US and abroad. She has been on the faculty at Johns Hopkins Bloomberg School of Public Health since 2008 in the Social and Behavioral Interventions Program within the Department of International Health. 